\title{
Genomic characterization of three marine fungi, including Emericellopsis atlantica sp. nov. with signatures of a generalist lifestyle and marine biomass degradation
}

Ole Christian Hagestad ${ }^{1 *}$ (D), Lingwei Hou ${ }^{2}$, Jeanette H. Andersen', Espen H. Hansen ${ }^{1}$, Bjørn Altermark ${ }^{3}$, Chun Li ${ }^{1}$, Eric Kuhnert ${ }^{4}$, Russell J. Cox ${ }^{4}$, Pedro W. Crous ${ }^{2}$, Joseph W. Spatafora ${ }^{5}$, Kathleen Lail ${ }^{6}$, Mojgan Amirebrahimi ${ }^{6}$, Anna Lipzen ${ }^{6}$, Jasmyn Pangilinan ${ }^{6}$, William Andreopoulos ${ }^{6}$, Richard D. Hayes ${ }^{6}$, Vivian $\mathrm{Ng}^{6}$, Igor V. Grigoriev ${ }^{6,7}$, Stephen A. Jackson ${ }^{8,9}$, Thomas D. S. Sutton ${ }^{8,10}$, Alan D. W. Dobson ${ }^{8,9}$ and Teppo Rämä ${ }^{1}$

\begin{abstract}
Marine fungi remain poorly covered in global genome sequencing campaigns; the 1000 fungal genomes (1KFG) project attempts to shed light on the diversity, ecology and potential industrial use of overlooked and poorly resolved fungal taxa. This study characterizes the genomes of three marine fungi: Emericellopsis sp. TS7, woodassociated Amylocarpus encephaloides and algae-associated Calycina marina. These species were genome sequenced to study their genomic features, biosynthetic potential and phylogenetic placement using multilocus data. Amylocarpus encephaloides and C. marina were placed in the Helotiaceae and Pezizellaceae (Helotiales), respectively, based on a 15-gene phylogenetic analysis. These two genomes had fewer biosynthetic gene clusters (BGCs) and carbohydrate active enzymes (CAZymes) than Emericellopsis sp. TS7 isolate. Emericellopsis sp. TS7 (Hypocreales, Ascomycota) was isolated from the sponge Stelletta normani. A six-gene phylogenetic analysis placed the isolate in the marine Emericellopsis clade and morphological examination confirmed that the isolate represents a new species, which is described here as E. atlantica. Analysis of its CAZyme repertoire and a culturing experiment on three marine and one terrestrial substrates indicated that E. atlantica is a psychrotrophic generalist fungus that is able to degrade several types of marine biomass. FungiSMASH analysis revealed the presence of 35 BGCs including, eight non-ribosomal peptide synthases (NRPSs), six NRPS-like, six polyketide synthases, nine terpenes and six hybrid, mixed or other clusters. Of these BGCs, only five were homologous with characterized BGCs. The presence of unknown BGCs sets and large CAZyme repertoire set stage for further investigations of E. atlantica. The Pezizellaceae genome and the genome of the monotypic Amylocarpus genus represent the first published genomes of filamentous fungi that are restricted in their occurrence to the marine habitat and form thus a valuable resource for the community that can be used in studying ecological adaptions of fungi using comparative genomics.
\end{abstract}

KEYWORDS: Bioprospecting, Genome mining, Illumina, Lignocellulolytic enzymes, Physiology, Taxonomy, 1 new taxon

\footnotetext{
* Correspondence: olehagestad@gmail.com

'Marbio, The Norwegian College of Fishery Science, Department at Faculty of Biosciences, Fisheries and Economics, UiT The Arctic University of Norway,

Tromsø, Norway

Full list of author information is available at the end of the article
}

(c) The Author(s). 2021 Open Access This article is licensed under a Creative Commons Attribution 4.0 International License, which permits use, sharing, adaptation, distribution and reproduction in any medium or format, as long as you give appropriate credit to the original author(s) and the source, provide a link to the Creative Commons licence, and indicate if changes were made. The images or other third party material in this article are included in the article's Creative Commons licence, unless indicated otherwise in a credit line to the material. If material is not included in the article's Creative Commons licence and your intended use is not permitted by statutory regulation or exceeds the permitted use, you will need to obtain permission directly from the copyright holder. To view a copy of this licence, visit http://creativecommons.org/licenses/by/4.0/. 


\section{INTRODUCTION}

The first genome of a fungus, Saccharomyces cerevisiae, was sequenced in 1996 (Goffeau et al. 1996). Subsequent developments in technology have made sequencing much more affordable, and the number of fungal genome and transcriptome sequencing projects has increased exponentially resulting in 1886 genomes being available in 2020 (Grigoriev et al. 2014; Sharma 2015; NCBI 2021). Most of the early sequencing efforts were focused on terrestrial ecologically or economically significant fungi, crop-pathogens, or fungi related to human health (Sharma 2015). Despite the effort so far, one issue in comparative genomics is the lack of available genomic data and proper taxonomic representation of the known taxa (Naranjo-Ortiz and Gabaldón 2019; Lücking et al. 2020). This is especially noticeable among marine fungi, where few genomes are available compared to terrestrial fungi. The 1000 fungal genomes (1KFG) project wants to address these issues and answer questions regarding ecologically and taxonomically overlooked fungi like marine fungi in poorly resolved taxa, such as Helotiales (Leotiomycetes). By making their genomes publicly available, 1KFG contributes to better elucidate the general features of marine fungi (Grigoriev et al. 2011; Grigoriev et al. 2014).

The marine environment is vastly different from the terrestrial environment, leading to distinct adaptations of the organisms living there. Such adaptations may be unique enzymes that withstand low or high temperatures, pressure or salt concentrations, and potent signaling molecules and sensitive receptors, specific pigments, and other unique metabolites (Van Noort et al. 2013; Kis-Papo et al. 2014; Rédou et al. 2015; Oey 2016; Fouillaud et al. 2017; Huang et al. 2017; Trincone 2018). There are many substrates available in the marine environment that are different compared to terrestrial substrates. Such substrates include polysaccharides such as laminarin, carrageenan, fucoidan, alginate, ulvan, galactans, porphyrin, agarose and chitin that do not occur in terrestrial sources or have different modifications such as sulfation (Barbosa et al. 2019). Fungal enzymes utilizing specific marine polysaccharides, such as glycoside hydrolase family 29 (GH29) linked to the degradation of algal fucoidan, GH107 linked to sulfated fucans, GH78 and GH105 linked to ulvan and GH18 and GH82 linked to carrageenan, are of interest for industrial processing. These enzymes make sugars bioavailable in feed for aquaculture and agriculture, usable in the production of specific polysaccharides for pharmaceutical purposes or as a carbon source for bioenergy production. Marine microorganisms also communicate with each other and protect themselves using secondary metabolites. Because the water dilutes any secreted molecules, the secondary metabolites have to be potent and they are therefore of special pharmaceutical interest as potential drugs (Berteau et al. 2002; Haefner 2003; Michel et al. 2006; Collén et al. 2014; Vickers et al. 2018; Reisky et al. 2019; Carroll et al. 2020; Dobrinčić et al. 2020).

Some of the fungi frequently observed in the marine environment include Acremonium-like fungi that are a polyphyletic assembly of mostly indistinct, hyaline, simple, asexual fungi. These fungi are isolated from macroalgae, invertebrates and sediments (Zuccaro et al. 2008; Duc et al. 2009; Loque et al. 2010; Paz et al. 2010; Mouton et al. 2012; Zhang et al. 2013; Rédou et al. 2015; Zhang et al. 2015; Lee et al. 2019). Binomially named Acremonium fungi are found within Glomerellales, Hypocreales, Sordariales, Cephalothecales (Cephalothecaceae) and Leotiomycetes showing how Acremonium is used collectively on phylogenetically distinct, but often morphologically indistinct fungi (Summerbell et al. 2011). Many of these fungi have close sequence similarity to sexual reproductive morph of described species and likely represent the asexual morphs of these species (Summerbell et al. 2011). Some of the Acremonium-like taxa within the Emericellopsis clade are marine, specifically those closely related to E. maritima and A. fuci, whereas terrestrial isolates form a distinct clade (Zuccaro et al. 2004). Alkali-tolerant soda soil fungi seem to have derived from the marine lineage and are nested in their own subclade within the marine clade (GrumGrzhimaylo et al. 2013). This concept of three ecological clades is challenged by recent research based on nuclear ribosomal DNA (nrDNA) ITS1-5.8S-ITS2 region (ITS) and $\beta$-tubulin (tub2) phylogeny and should be retested with multilocus gene phylogenies when new species are described (Gonçalves et al. 2020). Despite frequent phylogenetic studies and descriptions of new species, relatively few Acremonium-like fungi have available genome sequences. For Emericellopsis, there are no reference genomes available (Grigoriev et al. 2014; NCBI Resource Coordinators 2018). From chemical studies, it is known that species within the genus of Acremonium and Emericellopsis can produce a range of known bioactive metabolites (Argoudelis et al. 1974; Rogozhin et al. 2018; Hsiao et al. 2020). Despite evidence of secondary metabolite production, our understanding of the full biosynthetic potential of Emericellopsis species remains limited.

Calycina marina is a non-lichenized discomycetous fungus that is exclusively found on decaying seaweeds and has been collected all over the northern Europe (Baral and Rämä 2015; GBIF Secretariat 2021). Calycina marina is unique in both habitat, substrate and morphology compared to its closest relatives in Calycina that are terrestrial species (Baral and Rämä 2015). It is also peculiar in the sense that it is one of the few marine discomycetes compared to the terrestrial environment with 
hundreds of discomycetous species. Amylocarpus encephaloides is another strictly marine fungus that occurs on wood in the tidal zone (Prasannarai and Sridhar 2004). The fungus has a unique way of degrading wood that is similar to brown rot, but distinct from it, which may involve industrially interesting CAZymes (Prasannarai and Sridhar 2004). The fungus has been reported from in the Atlantic, Pacific and Indian Ocean (Prasannarai and Sridhar 2004; GBIF Secretariat 2021).

Here, we provide a thorough taxonomic and genomic description of the first fully sequenced Emericellopsis species. To further contribute to the knowledge of marine fungi, we include a brief description of the genomes of two marine fungi, Calycina marina and Amylocarpus encephaloides (Helotiales, Ascomycota), and resolve their phylogeny based on multilocus data extracted from genome sequences.

\section{MATERIALS AND METHODS}

In this manuscript we adhere to italicizing Latin names of organisms and higher order taxonomic ranks as discussed in Thines et al. (2020). Several of the methods used have previously been published and are only briefly described here.

\section{Sampling and isolate information}

The isolation method of the isolate TS7 was previously described in Batista-García et al. (2017). Emericellopsis sp. TS7 (Class Sordariomycetes, Order Hypocreales, Family Hypocreales incertae sedis) was obtained from the sponge Stelletta normani (Class Demospongiae, Order Astrophorida, Family Ancorinidae) collected on 16th June 2010 from $1350 \mathrm{~m}$ depth in the Atlantic Ocean $\left(54.0613^{\circ} \mathrm{N}, 12.5518^{\circ} \mathrm{W}\right)$, off the west coast of Ireland using a remote operated vehicle Holland I on board the R.V. Explorer (Kennedy et al. 2014). Briefly, $1 \mathrm{~mL}$ of the macerated sponge material was serially diluted and $100 \mu \mathrm{L}$ of each dilution was inoculated on agar plates with either malt extract agar-artificial seawater (ASW) or potato dextrose agar-ASW (DIFCO). Axenic cultures were obtained after two passages from the primary isolation. The fungus is accessible in the fungal collection of the School of Microbiology at University College Cork, under accession code TS7, and the Westerdijk Fungal Biodiversity Institute (CBS-KNAW) under the accession CBS 147198. Emericellopsis sp. TS7 was selected for full genome sequencing in the 1KFG project due to the lack of sequenced Emericellopsis species, its marine origin, promising antibacterial activity against gram-negative bacteria in initial bioactivity testing and as a putative novel species (Jackson et al. 2016).

Isolation of C. marina TRa3180A (Class Leotiomycetes, Order Helotiales, Family Pezizellaceae) was described in Baral and Rämä (2015). Spores from apothecia growing on decaying Ascophyllum nodosum (Class Phaeophyceae, Order Fucales, Family Fucaceae) at the entrance to Portsmouth Harbor, Portsmouth, Hampshire, England, were inoculated and isolated on 0.2SeaMEA $(4 \mathrm{~g} / \mathrm{L}$ malt extract agar with sterile filtered seawater) with antibiotics. The fungus was deposited at the Norwegian marine biobank (Marbank) with the accession number M16FUN0001.

Isolation of $A$. encephaloides TRa018bII (Class Leotiomycetes, Order Helotiales, Family Helotiaceae) was described in Rämä et al. (2014). Spores from a cleistothecium on decaying Betula sp. (Class Magnoliopsida, Order Fagales, Family Betulaceae) at $70.22874993^{\circ}$ $\mathrm{N}, 19.68153674^{\circ} \mathrm{E}$, Troms, Norway, were isolated on 0.2SeaMEA. The fungus was deposited at the Norwegian marine biobank (Marbank) with the accession number M15FUN0043.

\section{Morphological study}

Emericellopsis sp. TS7 was incubated on oatmeal agar (OA), potato dextrose agar (PDA) and malt extract agar (MEA) (recipes in Crous et al. (2019)) for 21 days at $25^{\circ} \mathrm{C}$. The cultures where then examined using a dissecting and compound light microscope equipped with differential interference contrast. Morphological characteristics were described and compared to closely related species.

\section{Growth characterization}

Growth requirements of Emericellopsis sp. TS7 was characterized by incubation on four different substrates (0.4\% malt extract, $0.3 \%$ chitin flakes (Sigma), 0.3\% fucoidan-rich extracts from Ascophyllum and Fucus (Non-commercial, Algaia, France) and 0.3\% aqueous extract (freeze dried sponge material was macerated and extracted using distilled water for $3 \mathrm{~h}$, the mixture was centrifuged and the aqueous phase was freeze dried. The resulting sample was then fractioned in six fractions and the most polar fraction were used for the agar) from Stelletta cf. normani (M15034-0-W01, Marbank, Norway), all on $1.5 \%$ agar, Sigma) and three different salinities (Distilled water, 50\% seawater and seawater) was performed in triplicate. In addition, each medium was incubated at four different temperatures, $2{ }^{\circ} \mathrm{C}, 10^{\circ} \mathrm{C}$, $15^{\circ} \mathrm{C}$ and $25^{\circ} \mathrm{C}$, to determine optimum growth temperature on the different media. The plates were incubated for a total of 43 days. Growths were recorded at day $3,5,10,15,21,27,31,38$ and 43 . Distilled water agar (1.5\% agar) was used as a control medium.

\section{Cultivation for nucleic acid extraction}

For DNA and RNA extractions, mycelium from liquid seed cultures of Emericellopsis sp. TS7, A. encephaloides and $C$. marina in 0.2ASME medium $(4 \mathrm{~g} / \mathrm{L}$ malt extract, 
$40 \mathrm{~g} / \mathrm{L}$ artificial sea salts (Sigma), MilliQ-water - hereafter MilliQ) were inoculated in $250 \mathrm{~mL}$ of the same medium in $1000-\mathrm{mL}$ baffled culture flasks. The media constituents were dissolved in MilliQ. All media were autoclaved at $121^{\circ} \mathrm{C}$ for $30 \mathrm{~min}$ before inoculation. Incubations were performed at $10-16^{\circ} \mathrm{C}$ at $140 \mathrm{rpm}$ (shaking for liquid cultures only). After 13 days the culture was harvested by vacuum filtration through Miracloth (Merck) and the mycelium was subsequently placed in aluminum foil and stored at $-80{ }^{\circ} \mathrm{C}$ until processing.

\section{Isolation of nucleic acids}

Genomic DNA from Emericellopsis sp. TS7, A. encephaloides and C. marina mycelium was isolated using Quick-DNA Fungal/bacterial Miniprep Kit (Zymo Research) according to supplier's instructions. The DNA quality was checked by three methods: First, DNA degradation was checked using gel electrophoresis on $1 \%$ TBE (Life technologies) UltraPure agarose (Life technologies) gel stained by GelRed (BioTium) that was run at $180 \mathrm{~V}$ for $20 \mathrm{~min}$ after loading the samples using Agarose gel loading dye (Amresco). Samples were compared to GeneRuler High Range DNA ladder (ThermoFisher). Secondly, NanoVue Plus (GE healthcare) measurement of wavelength ratio was used to control for contamination and estimate concentration. Finally, Qubit (Invitrogen) measurement using Qubit dsDNA BR Assay Kit (Invitrogen) was used for accurate concentration determination. The DNA sample was stored at $80^{\circ} \mathrm{C}$.

Total RNA from Emericellopsis sp. TS7, A. encephaloides and C. marina mycelium was isolated using Quick-RNA Fungal/Bacterial Miniprep Kit (Zymo Research) according to the supplier's protocol. All MilliQ used for RNA extraction were treated with diethyl pyrocarbonate (DEPC - Sigma). Quality control was performed using the same methods as for DNA with the exception of using RiboRuler High Range RNA ladder (ThermoFisher) for gel electrophoresis and Qubit RNA BR Assay Kit (Invitrogen) for concentration determination.

\section{DNA sequencing and assembly}

The draft genomes of Emericellopsis sp. TS7, C. marina and $A$. encephaloides were sequenced at the DOE Joint Genome Institute (JGI) using Illumina technology. For genome sequencing, $100 \mathrm{ng}$ of DNA was sheared to 300 bp using the Covaris LE220 and size selected using SPRI beads (Beckman Coulter). The fragments were treated with end-repair, A-tailing, and ligation of Illumina compatible adapters (IDT, Inc) using the KAPA-Illumina library creation kit (KAPA biosystems). Illumina Regular Fragment, $300 \mathrm{bp}$, standard shotgun library (STD) and long insert, $3000 \mathrm{bp}$, mate pair library (sLMP) were constructed and sequenced using Illumina NovaSeq. All raw Illumina sequence data were filtered for artifact/ process contamination using the JGI QC pipeline (Supplementary data 1 ). An automated attempt was made to reassemble any potential organelle (mitochondrion) from the filtered reads and remove any organelle-matching reads with kmer matching against the resulting contigs with an in-house tool. An assembly of the target genome was generated using the resulting non-Organelle reads with SPAdes v3.12.0 (Bankevich et al. 2012) using the following parameters [--phred-offset 33 --cov-cutoff auto -t 16 -m 115 -k 25,55,95 --careful]. Similar methodology, employing the UNITE rDNA database (Kõljalg et al. 2013), was used to reassemble the ribosomal DNA from the filtered reads.

Completeness of the euchromatic portion of the genome assemblies were assessed by aligning assembled consensus RNA sequence data with bbtools v38.31 bbmap.sh $[\mathrm{k}=13$ maxindel $=100,000$ customtag ordered nodisk] and bbest.sh [fraction $=85$ ] (Bushnell 2014). This was a routine test by JGI to determine whether significant portions of the genomes were missing.

\section{RNA library creation, read processing and De novo assembly}

For transcriptomics, plate-based RNA sample prep was performed on the PerkinElmer Sciclone NGS robotic liquid handling system using Illumina's TruSeq Stranded mRNA HT sample prep kit utilizing poly-A selection of mRNA following the protocol outlined by Illumina in their user guide:

https://support.illumina.com/sequencing/sequencing_ kits/truseq-stranded-mrna.html, and with the following conditions: total RNA starting material was $1 \mu \mathrm{g}$ per sample and 8 cycles of PCR was used for library amplification. The prepared libraries were then quantified using KAPA Biosystem's next-generation sequencing library qPCR kit and run on a Roche LightCycler 480 real-time PCR instrument. The quantified libraries were then multiplexed with other libraries, and the pool of libraries was then prepared for sequencing on the Illumina NovaSeq 6000 sequencing platform using NovaSeq XP v1 reagent kits, S4 flow cell, following a $2 \times 150$ indexed run recipe.

Raw reads were filtered and trimmed using the JGI QC pipeline resulting in the filtered fastq file (". filterRNA.fastq.gz files). Using BBDuk (Bushnell 2014), raw reads were evaluated for artifact sequence by kmer matching $(\mathrm{kmer}=25)$, allowing 1 mismatch and detected artifact was trimmed from the $3^{\prime}$ end of the reads. RNA spike-in reads, PhiX reads and reads containing any Ns were removed. Quality trimming was performed using the phred trimming method set at Q6. Finally, following trimming, reads under the length threshold were 
removed (minimum length 25 bases or $1 / 3$ of the original read length - whichever is longer).

Filtered fastq files were used as input for de novo assembly of RNA contigs. Reads were assembled into consensus sequences using Trinity (v2.3.2) (Grabherr et al. 2011). Trinity was run with the --normalize_reads (Insilico normalization routine) and --jaccard_clip (Minimizing fusion transcripts derived from gene dense genomes) options.

\section{Genome annotation and functional annotation}

The genome was processed through the JGI Fungal Annotation Pipeline according to the Fungal Genome Annotation Standard Operating Procedure available at https://mycocosm.jgi.doe.gov/programs/fungi/ FungalGenomeAnnotationSOP.pdf (Grigoriev et al. 2014). Briefly, gene models were iteratively improved using several gene-predicting tools and comparing it to the RNA transcriptome. Functional annotation was performed using SignalP (Petersen et al. 2011), TMHMM (Krogh et al. 2001), InterProScan (Hunter et al. 2009), SwissProt (Uniprot Consortium 2013) and KOG (Koonin et al. 2004). Finally, KEGG (Kanehisa et al. 2012) hits were used for EC numbers and map to metabolic pathways, while Intepro and SwissProt were used to map gene ontology (GO) terms. Core Eukaryotic Genes Mapping Approach (CEGMA) was used to make a set of reliable genes and determine the completeness of the gene annotation (Parra et al. 2007; Parra et al. 2009).

In addition to the annotations done by JGI, a functional annotation of the Carbohydrate Active Enzymes was performed using the dbCAN2 meta server (Zhang et al. 2018). Annotations were assigned using HMMER (Eddy 2020), Hotpep (Busk et al. 2017) and DIAMOND (Buchfink et al. 2015) on protein FASTA sequence. Domains were assigned by HMMER or if HMMER had no results, by HotPep and DIAMOND as long as both did predicted the same domains. Only genes where two tools had hits were included as recommended by dbCAN2s manual. For comparison with other fungi, two terrestrial and one marine genome were downloaded, Acremonium chrysogenum ATCC 11550 (Accession GCA 000769265.1; Terfehr et al. 2014), Aspergillus niger (Accession GCA_000230395.2; Andersen et al. 2011) and Sarocladium strictum ("Sarocladium schorii" Accession GCA_900290465.1; Schor et al. 2018). The genome of $S$. strictum only had the assembly available on NCBI, and the annotation was received from the authors (Schor et al. 2018). Furthermore, CAZyme amino acid sequences were extracted and searched against the SulfAtlas database (http://abims.sb-roscoff.fr/sulfatlas/) and the catalytic domain pattern of sulfatases using PROSITE (Sigrist et al. 2002; De Castro et al. 2006; Barbeyron et al. 2016).
The annotated genomes were also uploaded on antiSMASH fungal version (v5.0) to detect biosynthetic gene clusters and assess the biosynthetic potential of the isolates (Blin et al. 2019). Border prediction was manually adjusted; genes with homology to biosynthetic genes or putative tailoring genes were included in the clusters and the clusters were compared to previously published clusters using clinker (Gilchrist and Chooi 2021). Finally, the amount of short simple repeats (SSR) was checked using the Repeat Finder v1.0.1 plugin within Geneious.

\section{Phylogeny}

For Emericellopsis sp. TS7: 27 reference sequences including 19 sequences from ex-type strains or cultures were included in the phylogenetic analyses (Supplementary data 2). Sequences for each gene were aligned individually using the E-INS-I and G-INS-I algorithms with PAM100 of MAFFT v7.388 (Katoh et al. 2002; Katoh and Standley 2013) in Geneious Prime v11.0.4 followed by manual adjustment of alignments. The dataset was concatenated in Geneious. PartitionFinder v2.1.1 (Lanfear et al. 2017) was run with the concatenated dataset consisting of the nrDNA genes, 18S, ITS and 28S, and the protein coding genes RNA polymerase II subunit 2 ( $r p b 2)$, transcription elongation factor 1 alpha (tef1) and tub2 with a single intron. For the protein coding regions, each position of the codon was split to different partitions. The PartitionFinder analyses were run with: models MrBayes, linked branchlengths, greedy search, and AICc and BIC model selection criterion (Lanfear et al. 2012). This suggested 12 partitions (using AICc), of varying models (Supplementary data 2). Parallel-MPI MrBayes v3.2.7a with beagle was run for 5.000.000 generations or until average standard deviation of split frequencies was below 0.01 with sampling each 2500 generations with the 12 partitions as suggested by ModelFinder (Ronquist et al. 2012). In addition, PhyML 3.0 was run from the webserver as a single partition with smart model selection using AIC, SPR tree search improvement and aBayes and aLRT SH-like fast likelihoodbased branch support search (Anisimova and Gascuel 2006; Guindon et al. 2010; Anisimova et al. 2011; Lefort et al. 2017). The model selected was GTR $+\mathrm{I}+\mathrm{G}$. The maximum-likelihood tree using aBayes can be found in Supplementary data 3.

For C. marina and A. encephaloides, the 15 gene datasets from Johnston et al. (2019) containing 265 taxa were downloaded and the genes from C. marina and A. encephaloides were aligned to each individual gene alignment before it was concatenated to a single multilocus dataset. The dataset from Johnston et al. (2019) was modified slightly by removing a few introns from protein coding genes and cutting edge alignments only present in a minority of sequences. The alignment was loaded into IQ- 
TREE v1.6.12, each gene with its own partition (Nguyen et al. 2014). IQ-TREE was run with the parameters [-m MFP -bb 10,000 -alrt 10,000 -nt AUTO], such that it selected the best model for each partition using ModelFinder (Kalyaanamoorthy et al. 2017), performed 10,000 ultrafast bootstraps (Minh et al. 2013) and 10,000 SHaLRT branchtests (Guindon et al. 2010).

\section{RESULTS}

\section{Genome features of Emericellopsis sp. TS7}

The Emericellopsis sp. TS7 genome was assembled into 114 scaffolds, with a total size of $27.3 \mathrm{Mbp}$, Table 1 . Mapping of RNA-Seq reads and de novo assembled contigs revealed that 99.2 and $97.3 \%$, respectively, mapped back to the genome. The mitochondrial genome was separately assembled into a single scaffold of $25,688 \mathrm{bp}$ and is likely to be circular. The genome characteristics of $A$. encephaloides and C. marina are presented at the end of the results section.

\section{Gene features and functional annotation of Emericellopsis} sp. TS7

The 9964 predicted gene models gave a gene density of 365 genes/Mbp. CEGMA estimated that $99.34 \%$ of the core genes were present, which indicates a nearly complete genome. There were 162 tRNAs and a single complete nrDNA region in the assembly. A total of 4331 $(43 \%)$ genes were generically annotated with hypothetical (3252) or expressed (1079) proteins. The MAT-1-1 mating locus associated with sexual reproduction was also identified via BLAST in the assembly.

A total of 5201 (52\%) genes were recognized as orthologous genes based on hits in the KOG database (Table 1), of these $1317(25 \%)$ received general functional predictions or were conserved genes with unknown functions (Supplementary data 4). This indicates that 4763 of the 9964 (47.8\%) predicted genes do not have characterized orthologs or are lineage specific genes. A small portion of these genes may be pseudogenes that are not functional or genes that have been incorrectly predicted from the annotation pipeline. The largest group of identified orthologs belonged to the posttranslational modification, protein turnover and chaperones category (483). Signal transduction (377), energy production and conversions (323), carbohydrate transport and metabolism (318) and translation, ribosomal structures and biogenesis (317) were the next four highly represented categories. Secondary metabolite biosynthesis, transport and catabolism (268) made up $2.5 \%$ of the functionally annotated orthologs.

Table 1 Overview of genome assembly and gene statistics for Emericellopsis sp. TS7, Calycina marina and Amylocarpus encephaloides

\begin{tabular}{|c|c|c|c|}
\hline Isolates & Emericellopsis sp. TS7 & C. marina & A. encephaloides \\
\hline \multicolumn{4}{|l|}{ Genome statistics } \\
\hline Genome assembly size (Mbp) & 27.3 & 34.21 & 46.29 \\
\hline Coverage & 225.6 & 185.26 & 127.83 \\
\hline \# of scaffolds & 114 & 1318 & 2381 \\
\hline$\#$ of scaffolds $>=2 k$ & 105 & 1168 & 1600 \\
\hline Scaffold L50 & 14 & 173 & 168 \\
\hline Scaffold N50 (Mbp) & 0.76 & 0.05 & 0.07 \\
\hline \# of gaps & 22 & 37 & 68 \\
\hline$\%$ of scaffold length in gaps & 0.0 & 0.0 & 0.0 \\
\hline Largest scaffold & 1.47 & 0.38 & 0.42 \\
\hline$\% \mathrm{GC}$ & 54.2 & 47.6 & 44.9 \\
\hline \multicolumn{4}{|l|}{ Transcriptome and gene models } \\
\hline EST mapped to genome (\%) & 99.2 & 98.8 & 99.0 \\
\hline Average gene length & 1832 & 1758 & 1770 \\
\hline exons per gene & 2.59 & 3.13 & 3 \\
\hline \# of gene models & 9964 & 9558 & 11,869 \\
\hline Genes/Mbp & 364.98 & 279.39 & 256.41 \\
\hline CEGMA (\%) & 99.34 & 99.34 & 99.54 \\
\hline $\mathrm{BGCs}$ & 35 & 21 & 34 \\
\hline CAZyme genes & 396 & 217 & 356 \\
\hline KOG annotated & 5201 & 4723 & 5413 \\
\hline KEGG annotated & 1969 & 1670 & 2041 \\
\hline
\end{tabular}


Of the 9964 genes, only 1969 were classified based on the KEGG database, Table 1. The largest group of these were enzymes with known functions but undetermined pathways (688) (Supplementary data 4). This was followed by enzymes involved in amino acid metabolism (618), carbohydrate metabolism (433), metabolism of complex carbohydrates (314), and biodegradation of xenobiotics (298). Pathways associated with biosynthesis of secondary metabolites had 99 enzymes assigned to it.

\section{Phylogenetic placement of Emericellopsis sp. TS7}

Preliminary ITS analysis and morphological characterization indicated that Emericellopsis sp. TS7 was likely a novel species and for this reason, a thorough multigene phylogenetic analysis was performed. A concatenation of nuclear nrDNA 18S, ITS and 28S, and the protein coding genes $r p b 2$, tef 1 and $t u b 2$ were made and run through MrBayes using 12 partitions with different models as suggested by PartitionFinder and PhyML using the smart model selection (Supplementary data 2). The Acremonium/Emericellopsis species split into three clades; terrestrial soil, marine, and alkaline or "soda soil" (Fig. 1) as previously reported by Grum-Grzhimaylo et al. (2013). Emericellopsis sp. TS7 was grouped in the marine clade as an early branch, closest to E. pallida and E. phycophila with maximum support values. All three major ecological clades have support in both Bayesian and maximum-likelihood models, while individual taxa and branches in some cases have different branching in Bayesian and maximum-likelihood trees. The terrestrial clade have long branches and polytomy, but it is also the clade with the largest portion of missing data $(70.1 \%$ missing 18S, rpb2 and tef1) compared to the marine and alkaline clade (20.1\% missing data). The alkaline clade contains E. cladophorae that was isolated from marine algae. Emericellopsis donezkii and E. enteromorphae were isolated from fresh water and marine algae, respectively. The three species, E. cladophorae, E. donezkii and E. enteromorphae, were all isolated from marine sources, but they do not group in the marine clade. However, all three lack sequence information for $18 \mathrm{~S}, 28 \mathrm{~S}, r p b 2$ and tef1.

\section{Growth characterization of Emericellopsis sp. TS7}

In order to examine the growth characteristics of Emericellopsis sp. TS7, the isolate was grown on different substrates, salinities and temperatures (Fig. 2). The fastest growth rate occurred at $25^{\circ} \mathrm{C}$ for all substrates and salinities. The preferred substrate was MEA and sponge extract, prepared with seawater. The slowest growth occurred on MEA prepared with distilled water. Generally, growth on media prepared with distilled water was

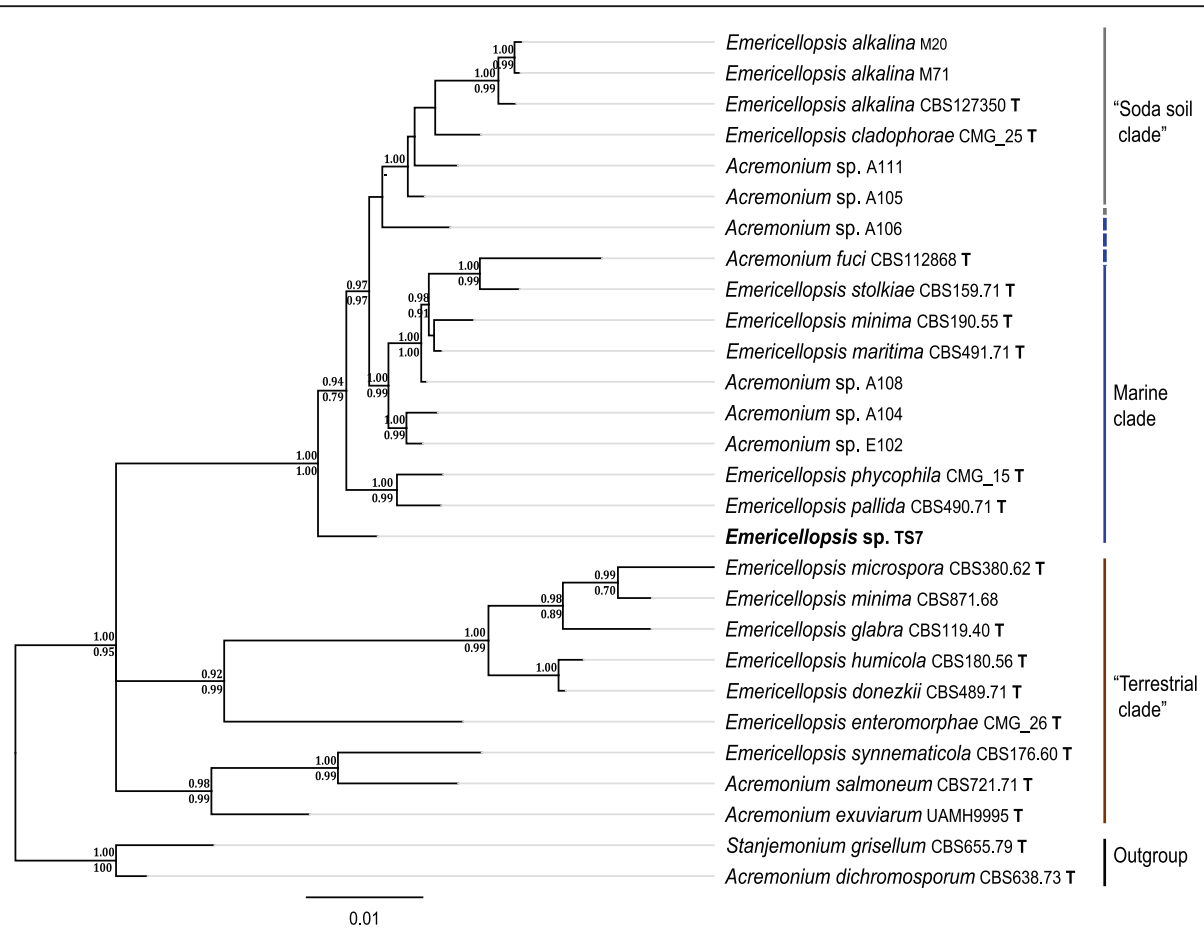

Fig. 1 Phylogenetic tree from MrBayes of the genus Emericellopsis based on a six gene multilocus alignment of available ex-type and representative sequences. Branch support values are from Bayesian posterior probability (top) and Maximum-likelihood aBayes support test (bottom). Branch length represents substitutions per sequence site. The taxon in bold is the studied fungus. The bold letter T denotes sequences of ex-type cultures. Accession numbers for each isolate are in Supplementary data 2, PhyML tree can be seen in Supplementary data 3 


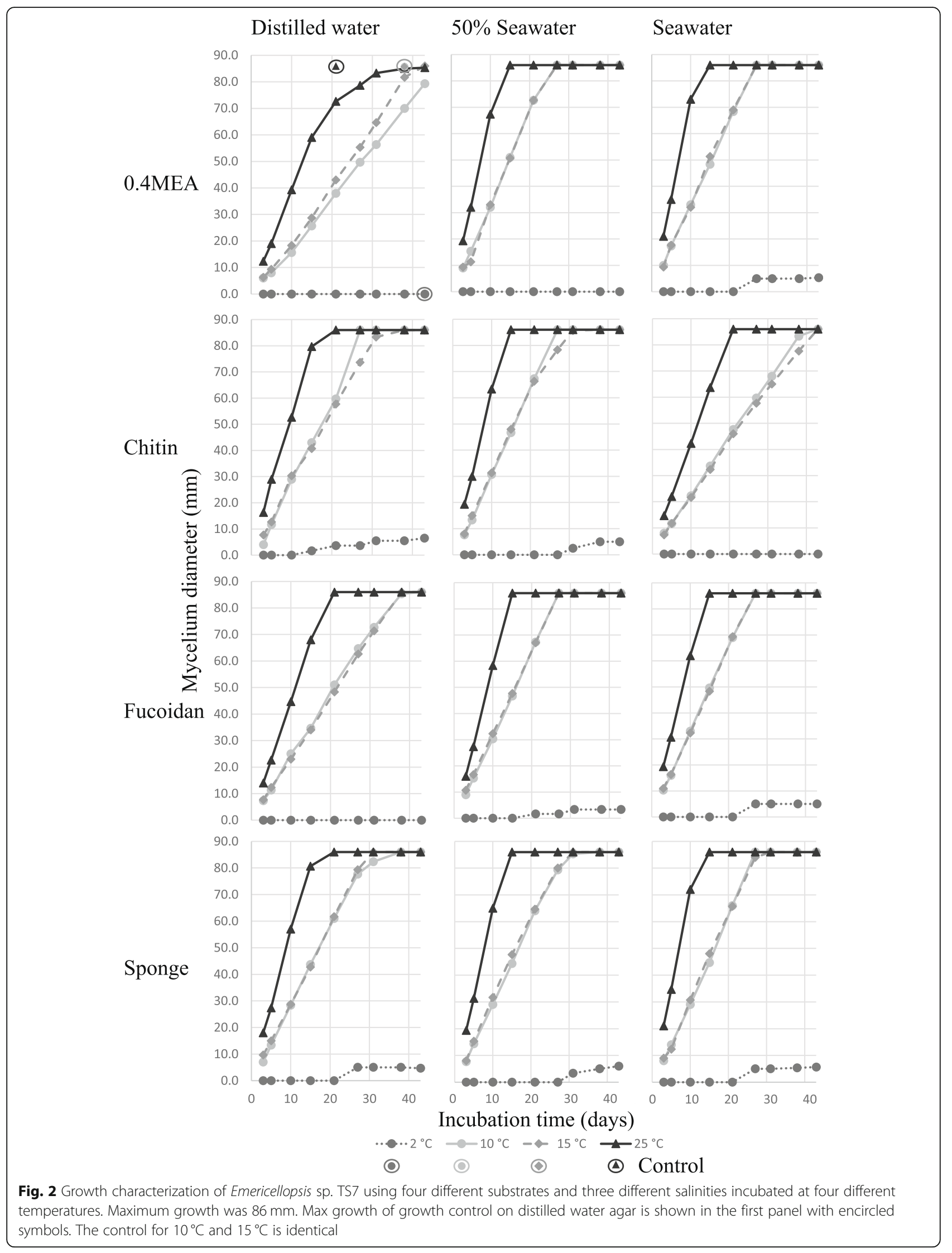


slower compared to salt containing media. Growth at $2{ }^{\circ} \mathrm{C}$ occurred for all salinities with sponge extract. Emericellopsis sp. TS7 on the control medium reached full growth within 21 days at $25^{\circ} \mathrm{C}, 38$ days at $10^{\circ} \mathrm{C}$ and $15{ }^{\circ} \mathrm{C}$, and no growth at $2{ }^{\circ} \mathrm{C}$. Growth on 0.4MEA medium without salt and chitin medium with salt was slower than the control medium.

\section{CAZymes and other industrially relevant genes}

The number of CAZymes in Emericellopsis sp. TS7 was 396 (3.97\% of total genes), of which 149 possessed secretory peptide signal indicating that they are likely to be secreted into the external environment or across other membranes (38\% of CAZymes). A comparison of Emericellopsis sp. TS7, A. encephaloides and C. marina with three other fungal genomes, namely $A$. niger, $S$. strictum and A. chrysogenum (two terrestrial/pathogens and one from sewage water outlet to the sea) indicated that Emericellopsis sp. TS7 had the second highest number of CAZyme genes (Fig. 3). A relatively high number of CAZymes in Emericellopsis sp. TS7 and A. chrysogenum had a secretory signal compared to the other species (38\% vs $23-33 \%)$. Emericellopsis sp. TS7 had a higher number of polysaccharide lyase (PL), glycosyl transferase (GT) and GH domains compared to the other marine isolates. Amylocarpus encephaloides on the other hand contained the highest number of carboxyl esterases (CEs), carbohydrate binding modules (CBMs) and auxiliary activity (AA) domains of the marine fungi. Calycina marina contained two PL8 (absent in the other studied fungi), which act on uronic acid, a common constituent of seaweeds (Ponce et al. 2003; Sánchez-
Machado et al. 2004). CAZyme genes are often modular with many genes containing one or more enzymatic domains along with CBMs that bind to substrates and have no catalytic function. Examples of this are the putatively secreted CAZyme gene 217,297 in Emericellopsis sp. TS7 with a GH18 and CBM18 domain (putative chitinase) or 546,426 (putative cellulase) with a CBM1, AA3 1 and AA8 domain (Fig. 4).

The different classes of CAZymes followed a similar putative secretion signal pattern in the fungi compared here (Supplementary data 5). Generally, few genes (4$6 \%$ ) with predicted GT activity contained putative signal peptide for secretion, but these are often involved in intracellular synthesis. Genes with PL activity contained secretion signal in $80-88 \%$ of cases, with the exception in C. marina and S. strictum that only had signal in 50 and $60 \%$ of genes, respectively. Amylocarpus encephaloides had the highest ratio of CBM containing genes with secretion signal (66.7\%) and C. marina had the lowest ratio of genes with secretion signal for all classes except GHs. For example, Emericellopsis sp. TS7 genes with AA had secretion signal in $42.3 \%$ of cases, CBM in $55.0 \%$, CE in $66.7 \%$, GH in $42.5 \%$, GT in $6.7 \%$ and PL in $88.2 \%$.

The domains that occurred in the highest numbers across the six genomes analyzed were associated with cellulose, hemicellulose, xylan, mannose, fucose, pectate, and chitin. In the secreted enzymes mainly cellulose-, chitin- and xylan-interacting domains were abundant. The unclassified domain GHO was found in Emericellopsis sp. TS7 (1), C. marina (1) and A. encephaloides (2). In total, Emericellopsis sp. TS7 had 176 different classes of CAZymes (Supplementary data 5).

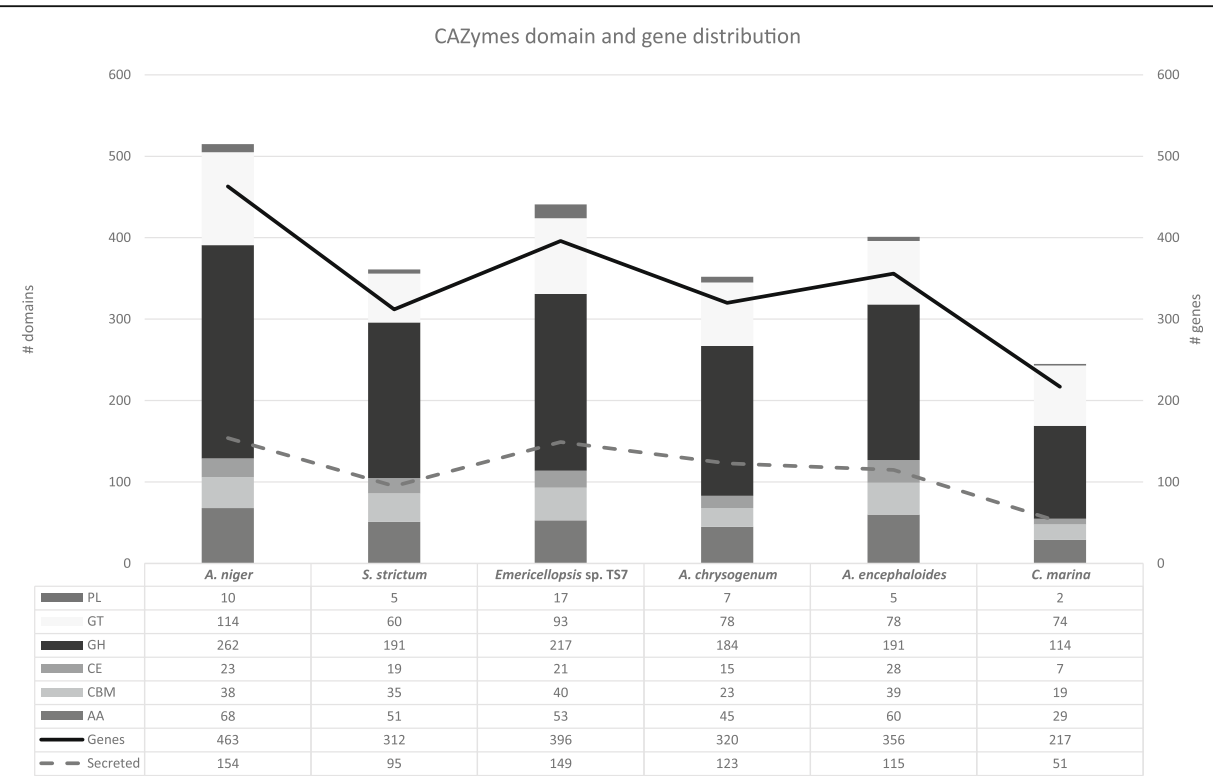

Fig. 3 Overview of the distribution of CAZymes in Emericellopsis sp. TS7 Amylocarpus encephaloides and Calycina marina and three other fungi. The lines indicate the number of genes and number of genes with putative secretion signal and uses the secondary Y-axis 


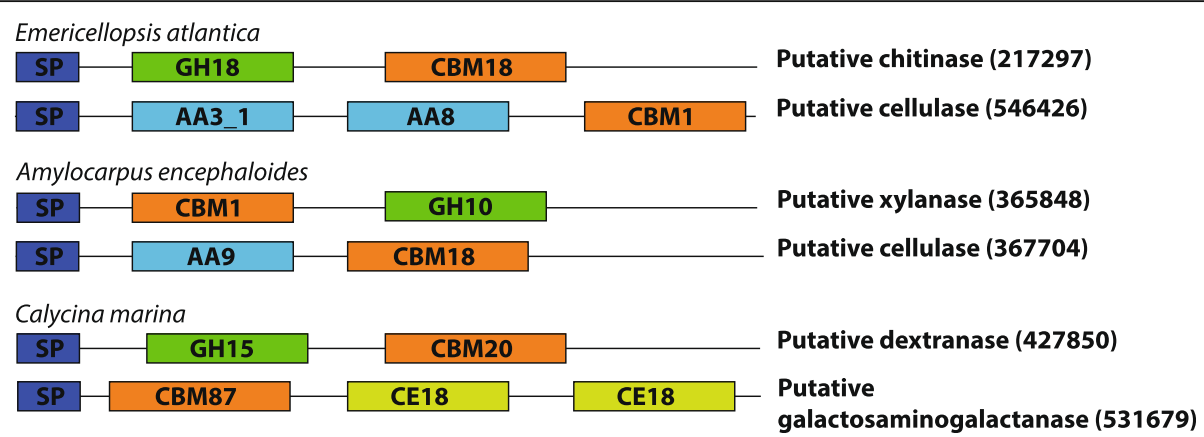

Fig. 4 Examples of putatively secreted modular CAZymes from Emericellopsis sp. TS7, Amylocarpus encephaloides and Calycina marina. The illustration is not to scale. SP - Secretion signal peptide, GH - Glycoside hydrolase, CBM - Carbohydrate binding module, AA - Auxiliary activity, CE - Carboxyl esterase. Number indicates enzyme class. Number in brackets is protein identifier

Emericellopsis sp. TS7 does not appear to possess genes encoding polyphenol oxidases or fucoidanase, but does have genes encoding fucosidase (GH29 and GH95), a fucose transporter and a few GTs with potential fucose activity (GT1 and GT31). In addition, Emericellopsis sp. TS7 also contains seven potential sulfatase genes based on the sulfatase catalytic site pattern (Barbeyron et al. 2016), but none of the domains are on CAZymes.

The gene for the industrially relevant enzyme phytase was also found (Lei et al. 2013) in Emericellopsis sp. TS7, C. marina and A. encephaloides, along with histidine acid phosphatases that share the same enzyme classification (EC 3.1.3.8) with phytase.
Biosynthetic gene clusters of Emericellopsis sp. TS7

A total of 35 biosynthetic gene clusters (BGCs) were predicted using antiSMASH, with 27 of these gene clusters being shown in Fig. 5. Eight are not included in the figure because they were solitary core genes not surrounded by other tailoring, transport or transcription genes or they were likely precursor genes in sterol synthesis such as the squalene and lanosterol synthase. The clusters contained a range of oxidoreductases, transcription factors, tailoring genes and transporters together with core biosynthetic gene(s). These BGCs included eight NRPS clusters, six NRPS-like clusters, nine terpene clusters, six polyketide synthase (PKS) clusters, three mixed NRPS-PKS clusters, one hybrid NRPS-PKS cluster, one phosphonate cluster and one indole cluster.

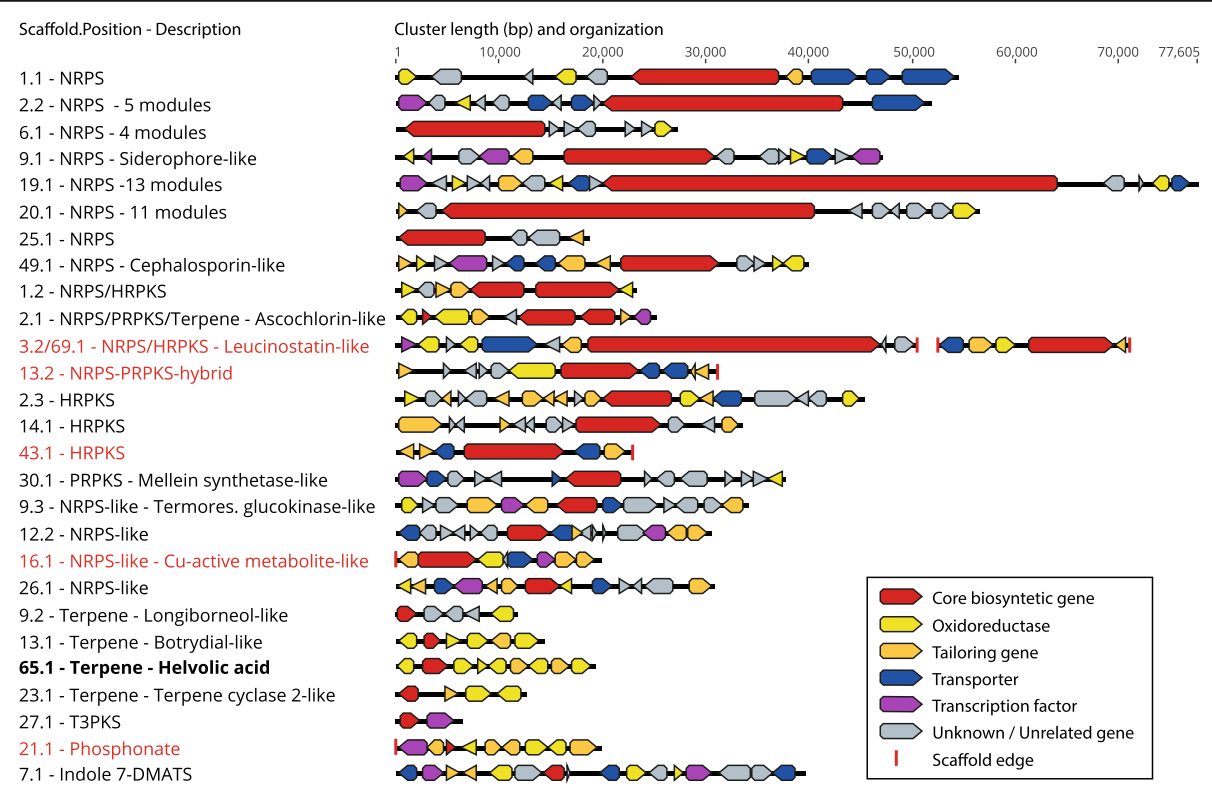

Fig. 5 Overview of BGC structure of the predicted clusters in Emericellopsis sp. TS7 colored after function. Clusters marked in red were on the end of scaffolds and may be incomplete. The leucinostatin-like cluster was split in two, but is presented as one cluster with a gap. Helvolic acid, produced by the cluster in bold, were detected in MS analyses of fermentation broths 
Several of the clusters had homology to known clusters according to KnownClusterBlast, these were further investigated by a synteny analysis using clinker (Gilchrist and Chooi 2021). Only the BGC for ascochlorin (Araki et al. 2019), leucinostatin A/B (Wang et al. 2016), botrydial (Pinedo et al. 2008), cephalosporin C (Terfehr et al. 2014) and helvolic acid (Mitsuguchi et al. 2009) showed a high degree of conserved genes in the Emericellopsis clusters (Supplementary data 6). Several of the NRPSgenes without homologous hits had a configuration of 4-13 modules according to antiSMASH.

Emericellopsis sp. TS7 was cultivated in several different media and the fermentation broths were extracted. The resulting fractions from the extracts showed antibacterial activity against Enterococcus faecalis, Streptococcus agalactiae and Staphylococcus epidermidis. No toxicity was detected against A2058 human melanoma cancer cells. Methods and details of bioactivity experiments can be found in Supplementary data 7.

\section{Genome description of Calycina marina}

The genome assembly of $C$. marina was more fragmented when compared to Emericellopsis sp. TS7. The assembly statistics reveal that the L50 was 173 with an N50 of $50 \mathrm{kbp}$ and the final assembly consisted of 1318 scaffolds with a total length of $34.2 \mathrm{Mbp}$. The number of predicted genes in C. marina was 9558, which was slightly fewer than in Emericellopsis sp. TS7 despite the fact that C. marina has a larger genome. Calycina marina distinguished itself from the other genomes analyzed in having comparatively few CAZyme genes, totaling 217; and the lowest proportion of potentially secreted CAZyme genes at 51 (24\% of CAZymes). The genome contained 21 potential BGCs distributed as nine NRPS/ NRPS-like, five PKS (including two type 3), three terpene, one indole, one hybrid, one aromatic prenyltransferases and one ribosomally synthesized and posttranslationally modified peptide (RiPP).

\section{Genome description of Amylocarpus encephaloides}

The genome assembly of $A$. encephaloides was also more fragmented than Emericellopsis sp. TS7 with an L50 value of 168 and N50 of $74 \mathrm{kbp}$. The genome assembly consisted of 2381 scaffolds with a total length of 46.3 Mbp, which was larger than that for Emericellopsis sp. TS7 and C. marina. The total number of predicted genes was 11,869 , which is the highest number among the three sequenced strains. Despite being fragmented, the genome was complete in terms of core gene presence with a CEGMA value of $99.56 \%$. Amylocarpus encephaloides had 356 CAZyme genes, of which 115 are potentially secreted. The genome showed a higher portion of CAZyme genes with CBM1 (Cellulose binding) modules and secretion of these (15 genes, $80 \%$ secreted).
Amylocarpus encephaloides also had the largest portion of CBM containing CAZymes with secretion signal in total $(66.7 \%)$. A total of 34 BGCs were detected in the genome, distributed as 14 PKS (one type 3), 10 NRPS/ NRPS-like, five terpene, four hybrid clusters and one RiPP.

\section{Phylogenetic placement of Amylocarpus encephaloides and Calycina marina within Helotiales}

A 15-gene multilocus phylogenetic analysis was performed using a slightly modified dataset of Johnston et al. (2019). Calycina marina was placed together with the rest of Calycina within Pezizellaceae, where it formed a monophyletic clade (Fig. 6). Amylocarpus encephaloides was placed within Helotiaceae on a branch with "Hymenoscyphus" repandus. "Hymenoscyphus" repandus was not placed together with the rest of the Hymenoscyphus that formed a distinct monophyletic clade. Both of these clades were within Helotiales, sensu Johnston et al. (2019).

\section{TAXONOMY}

Emericellopsis atlantica L.W. Hou, Crous, Rämä \& Hagestad, sp. nov.

MycoBank MB838493

\section{Fig. 7}

Etymology: atlantica, referring to the Atlantic Ocean where the fungus was found.

Diagnosis: Emericellopsis atlantica can be distinguished by the production of conidia with irregularshaped guttules, and longer phialides measuring 24.5$50(-64) \mu \mathrm{m}$. Furthermore, E. atlantica occasionally produces branched conidiophores. Emericellopsis atlantica differed by its longer conidiogenous cells, which were $19.0 \pm 7.5 \times 1.5 \pm 0.5 \mu \mathrm{m}$ in E. enteromorphae. Colonies of $E$. atlantica also grew faster than the three other marine species (Gonçalves et al. 2020).

Typus: Ireland, from $1350 \mathrm{~m}$ depth in the Atlantic Ocean ( $54.0613 \mathrm{~N}, 12.5518 \mathrm{~W})$, from the sponge Stelletta normani, 16 June 2010, T.D.S. Sutton (holotype CBS H24579, ex-type living culture TS7 = CBS 147198).

Description: Colonies after $21 \mathrm{~d}$ incubation at $25^{\circ} \mathrm{C}$ : On OA reaching $65 \mathrm{~mm}$ diam., flat, entire margin, dusty and rosy buff at centre, dirty white at periphery, reverse ochreous. On MEA reaching $70 \mathrm{~mm}$ diam., flat, entire margin, felty, pale ochreous at centre, dirty at periphery, reverse ochreous. On PDA reaching $80 \mathrm{~mm}$ diam., flat, entire margin, cottony, rosy buff at centre, buff at periphery, reverse buff. Mycelium consisting of branched, septate, hyaline, smooth- and thin-walled hyphae, up to $2 \mu \mathrm{m}$ wide. Conidiophores arising from submerged or superficial hyphae, sometimes radiating out from sterile coils formed by the mycelium, (sub-)erect or slightly curved, simple or poorly branched, ca. up to $66 \mu \mathrm{m}$ long, 


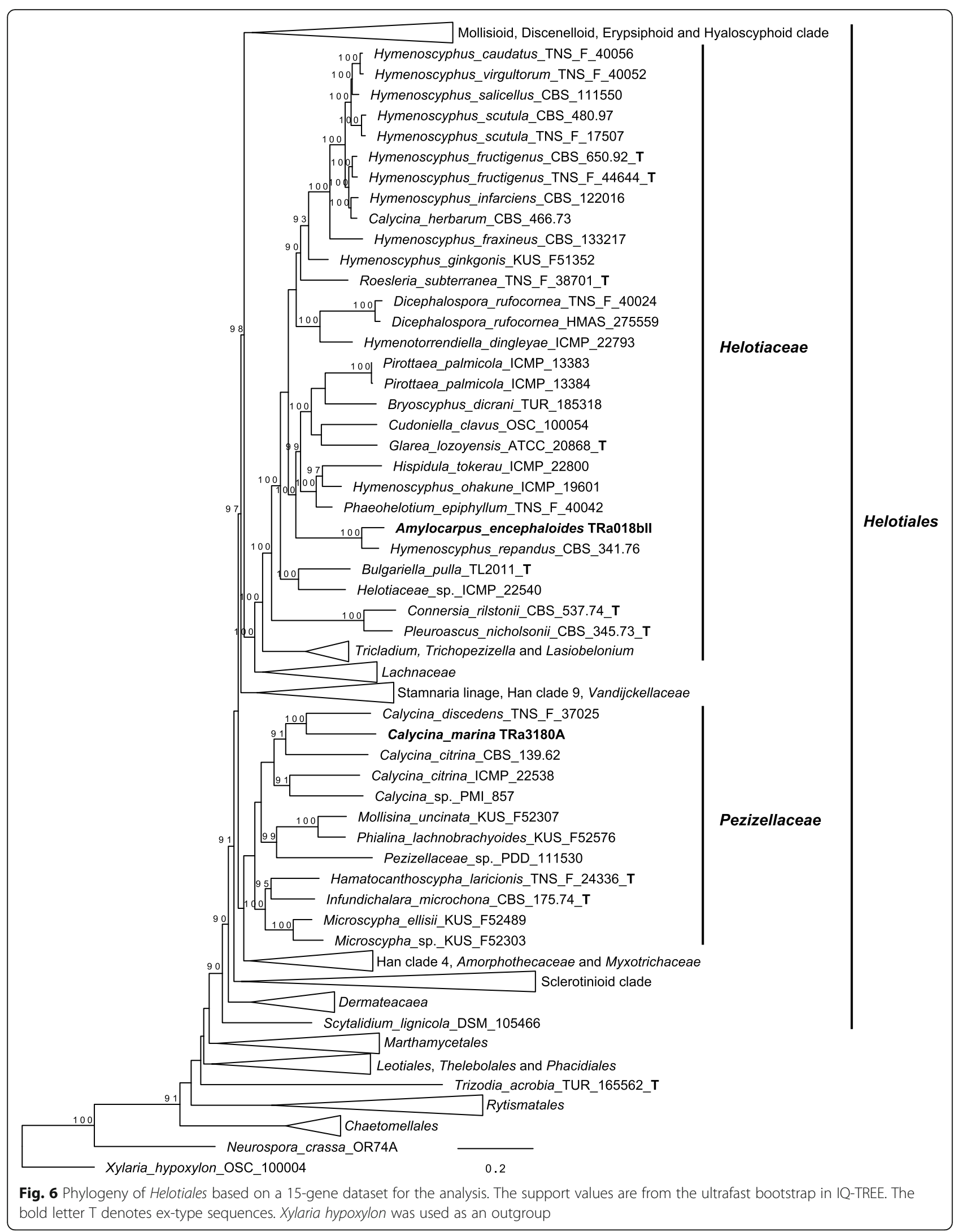



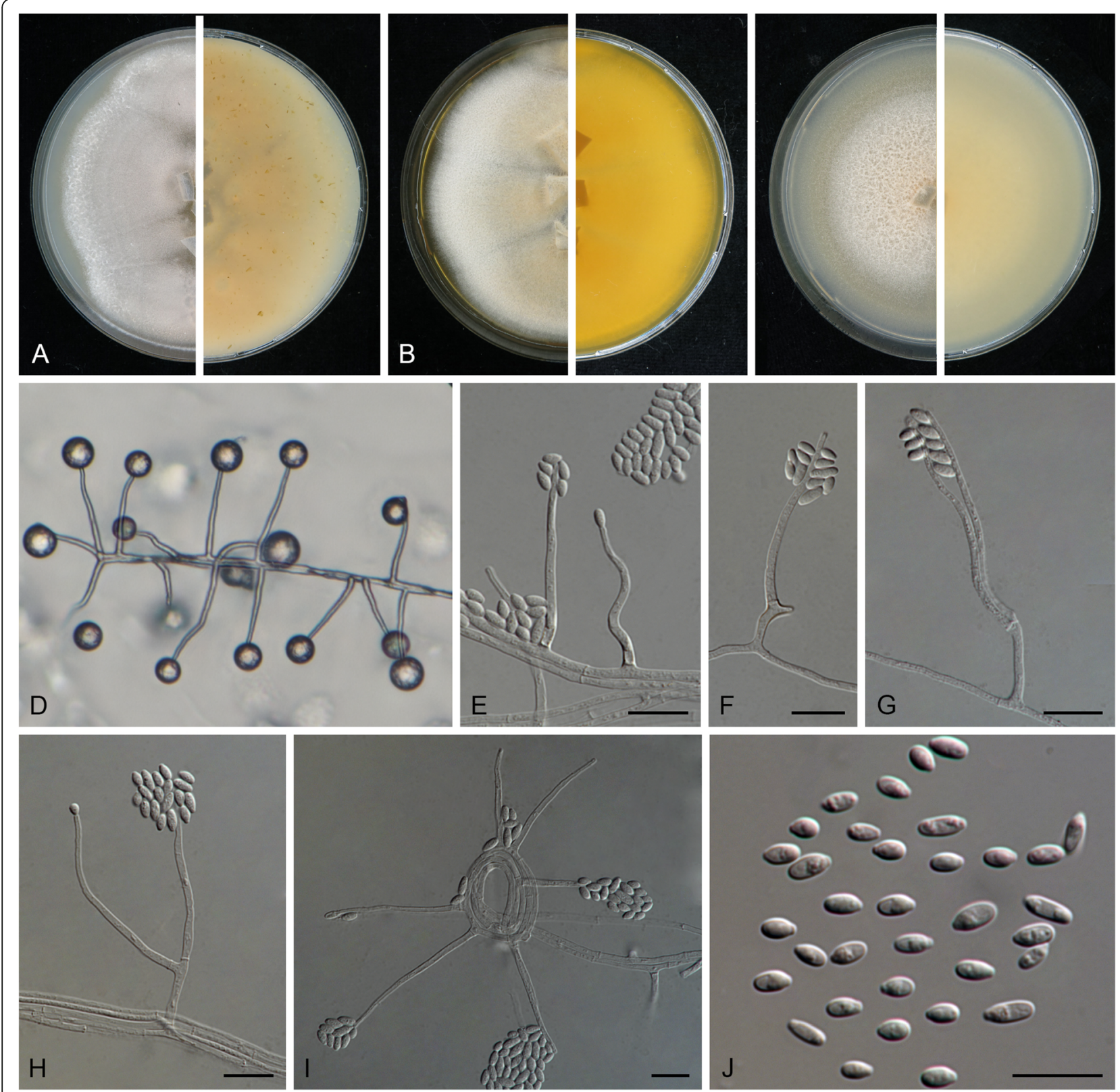

Fig. 7 Emericellopsis atlantica (ex-type CBS 147198). Colonies on OA (a), MEA (b) and PDA (c) after 21 d at 25 C. d-f, i Phialides. g-h. Branched conidiophores. $\mathbf{j}$ Conidia. Scale bars $=10 \mu \mathrm{m}$

$1.5-3 \mu \mathrm{m}$ wide at the base, hyaline, smooth-walled, with cell walls usually thicker than those of the vegetative hyphae. Conidiogenous cells integrated, monophialidic, terminal, lateral, straight to slightly flexuose, cylindrical, 24.5-50(-64) $\mu \mathrm{m}$ long, $1.5-2.5 \mu \mathrm{m}$ wide at the base, with inconspicuous collarette and periclinal thickening at the conidiogenous locus, hyaline, thick- and smoothwalled branched conidiophores. Conidia formed in globose slimy heads at the apex of phialides, obovoid or ellipsoidal with truncate base, aseptate, hyaline, thin- and smooth-walled, 3-6(-9) $\times 2-2.5 \mu \mathrm{m}$, with $1-2$ irregular shaped guttules. Chlamydospores not observed.

Sexual morph not observed.

Habitat/host: Only known from type. Isolated from the sponge Stelletta normani, collected in a marine environment.

Distribution: Currently unknown.

Notes: Emericellopsis atlantica is represented by a single isolate that clusters on a solitary branch basal to the clade containing the "Marine clade" and "Soda soil 
clade" of Emericellopsis. Morphologically, E. atlantica can be distinguished from other Emericellopsis spp. with comparable conidiophores and conidia by producing longer conidiogenous cells and conidia with irregularshaped guttules. Currently there are 26 entries listed in the genus Emericellopsis in Index Fungorum, including four varieties, E. terricola var. glabra, E. terricola var. terricola, E. synnematicola var. magna and E. synnematicola var. synnematicola (Van Beyma Thoe Kingma 1939; Mathur and Thirumalachar 1960; Backus and Orpurt 1961). Morphologically, Emericellopsis atlantica is distinct from other species in having longer conidiogenous cells, $24.5-50(-64) \mu \mathrm{m}$, which tend to be shorter than $50 \mu \mathrm{m}$ in most species, except for E. donezkii, E. koreana, E. microspora, E. mirabilis, E. pusilla and E. robusta, which again lack conidia with irregular-shaped guttules. Furthermore, conidia of E. atlantica $(3-9 \times 2-2.5 \mu \mathrm{m})$ are longer than those of $E$. donezkii $(2.5-6.5 \times 2-2.5 \mu \mathrm{m})$ and $E$. koreana $(3-5 \times 1.5-2.5 \mu \mathrm{m})$, and smaller than $E$. microspora (3.0-10.0 × 1.5-4.0 $\mu \mathrm{m})$, E. mirabilis $(6-11 \times$ $2.5-3 \mu \mathrm{m})$, E. pusilla $(4.5-10.5 \times 2.25-4.5 \mathrm{um})$ and E. robusta (13-17.5 × 3.8-4.5 um) (Malan 1952; Stolk 1955; Backus and Orpurt 1961; Mathur and Thirumalachar 1962; Gams 1971; Belyakova 1974; Phookamsak et al. 2019). For comparisons with morphologically similar and phylogenetically related species, see Table 2 .

Emericellopsis atlantica is also morphologically similar to some species belonging to Acremonium sect. Simplex (Gams 1971). However, these species have been transferred to Sarocladium (S. bactrocephalum, S. glaucum, S. kiliense, S. ochraceum, S. strictum; Summerbell et al. 2011), Parasarocladium (P. breve; Summerbell et al. 2018), or were clearly phylogenetically distant from Emericellopsis (Summerbell et al. 2011) based on phylogenetic analysis using nrDNA and actin sequences. Only A. larvarum lacks cultures or DNA sequence data but can be distinguished in having shorter conidiogenous cells $(14-22 \mu \mathrm{m})$, and producing synnemata (Gams 1971). Other "Acremonium" species that clustered in Emericellopsis include A. fuci, A. salmoneum and A. exuviarum, but they proved to be phylogenetically distant from E. atlantica (Gams 1975; Sigler et al. 2004; Zuccaro et al. 2004; Summerbell et al. 2011).

Material examined: Ireland, from $1350 \mathrm{~m}$ depth in the Atlantic Ocean $(54.0613 \mathrm{~N}, 12.5518 \mathrm{~W})$, from the sponge Stelletta normani, 16 June 2010, T.D.S. Sutton (holotype CBS H-24579, ex-type living culture TS7 = CBS 147198).

\section{DISCUSSION}

The driftwood-associated Amylocarpus encephaloides and seaweed-associated Calycina marina

Amylocarpus encephaloides and C. marina are both considered obligate marine fungi and are therefore of significant interest in sequencing campaigns. Amylocarpus encephaloides had the largest genome of the three genomes presented here, with about 2000 more genes than the two other fungal genomes. Despite the high gene count, A. encephaloides had fewer CAZymes than $E$. atlantica, but a higher the number of secreted CAZymes containing CBM1 and CBM87 compared to the other genomes. CBMs are important for binding to insoluble substrates such as cellulose (Boraston et al. 2004; Zhao et al. 2014). In addition, A. encephaloides had a higher number of CEs and AAs than the two other genomes. Specifically, it had seven AA1 laccases acting on phenolic substrates and can be involved in lignin degradation. AAs are often associated with degradation of lignin and the high amounts of CBMs, AAs and CEs shows an adaptation towards woody substrates that sporocarps of $A$. encephaloides are exclusively found on.

Calycina marina had the lowest number of genes, despite having a larger genome than E. atlantica. Calycina marina also had the fewest BGCs and a significantly smaller amount of CAZymes relative to the total gene count. The fungus had two CAZymes that were members of PL8 family. This class is acting on uronic acid which is a constituent of some types of fucoidan (Ponce et al. 2003). This indicates an adaptation towards living from the preferred substrate of occurrence. The fungus C. marina is found on decaying macroalgae in the upper part of the tidal zone. The quick colonization suggests that this fungus is already present in or on the algae before it is washed ashore (Baral and Rämä 2015). The relation of C. marina to its algal host needs to be examined more closely to determine of it is found inside (endophyte) or on the surface (epiphyte) of the algae before it is washed ashore using for example metagenomics studies.

The genome scaffolds of $A$. encephaloides and C. marina were significantly more fragmented than the assembly of $E$. atlantica. This is potentially due to a larger portion of repetitive elements which can complicate genome assemblies (Sotero-Caio et al. 2017; Tørresen et al. 2019). CEGMA analysis indicated that nearly all core genes were accounted for, so the genome can be considered complete with respect to core gene content. However, the many small contigs made it impossible to identify complete BGCs since many were located at the contig edges. The fragmentation could also reduce the number of BGCs that were detected.

\section{The genome of Emericellopsis atlantica}

The size of the genome assembly of Emericellopsis atlantica was $27.3 \mathrm{Mbp}$. The assembly was approximately 3 Mbp smaller than the average genome size of karyotyped Acremonium (Walz and Kück 1991) and $1.3 \mathrm{Mbp}$ smaller than the sequenced A. chrysogenum ATCC 
Table 2 Morphological comparison of Emericellopsis spp.

\begin{tabular}{|c|c|c|c|c|c|}
\hline Species & Colonies & $\begin{array}{l}\text { Growth } \\
\text { rate } \\
(\mathrm{mm} / \mathrm{d})\end{array}$ & Conidiogenous cells/Conidiophores & Conidial shape and size & References \\
\hline $\begin{array}{l}\text { E. atlantica sp. } \\
\text { nov. }\end{array}$ & $\begin{array}{l}\text { On PDA reaching } 74 \mathrm{~mm} \text { at } \\
14 \mathrm{~d} \text {; on } \mathrm{OA} \text { reaching } 56 \\
\mathrm{~mm} \text { at } 14 \mathrm{~d} \text {; on MEA } \\
\text { reaching } 58 \mathrm{~mm} \text { at } 14 \mathrm{~d} \text {, }\end{array}$ & $4.0-5.3$ & $24.5-50(-64) \times 1.5-2.5 \mu \mathrm{m}$ & $\begin{array}{l}\text { obovoid or ellipsoidal with } \\
\text { truncate base, } 3-6(-9) \times 2- \\
2.5 \mu \mathrm{m} \text {, with } 1-2 \text { irregular } \\
\text { shaped guttules }\end{array}$ & This study \\
\hline E. alkalina & $\begin{array}{l}\text { On MEA }(\mathrm{PH}=6.5) \text { growing } \\
\text { slower, reaching } 32-38 \mathrm{~mm} \\
\text { diam in } 10 \mathrm{~d} \text {. }\end{array}$ & $3.2-3.8$ & $\begin{array}{l}20-35 \times 1.5-1.8 \mu \mathrm{m} \text {, sometimes lateral } \\
\text { branches form }\end{array}$ & $\begin{array}{l}\text { narrowly ellipsoidal, } 3.5-6 \times \\
1.8-2.2 \mu \mathrm{m}\end{array}$ & $\begin{array}{l}\text { Grum- } \\
\text { Grzhimaylo } \\
\text { et al. (2013) }\end{array}$ \\
\hline E. cladophorae & $\begin{array}{l}\text { On OA reaching } 36 \mathrm{~mm} \text { in } \\
21 \mathrm{~d}\end{array}$ & 1.7 & $\begin{array}{l}21.0 \pm 5.0 \times 2.0 \pm 0.5 \mu \mathrm{m} \text {, sometimes lateral } \\
\text { branches form }\end{array}$ & $\begin{array}{l}\text { circular to oblong- } \\
\text { ellipsoidal, } 5.5 \pm 2.5 \times 3.5 \pm \\
1.5 \mu \mathrm{m}\end{array}$ & $\begin{array}{l}\text { Gonçalves } \\
\text { et al. (2020) }\end{array}$ \\
\hline E. donezkii & $\begin{array}{l}\text { On PDA reaching } 30 \mathrm{~mm} \text { in } \\
9 \mathrm{~d}\end{array}$ & 3.3 & $(20-)$ 30-45 (-80) × 1.5-2 $\mu \mathrm{m}$ & $\begin{array}{l}\text { ovoid-cylindical, ellipsoidal } \\
\text { or sometimes inaequilateral } \\
\text { subincurved, (2.5-) } 4-5.2(- \\
6.5) \times 2-2.5 \mu \mathrm{m}\end{array}$ & $\begin{array}{l}\text { Belyakova } \\
(1974)\end{array}$ \\
\hline $\begin{array}{l}\text { E. } \\
\text { enteromorphae }\end{array}$ & $\begin{array}{l}\text { On OA reaching } 42 \mathrm{~mm} \text { in } \\
21 \mathrm{~d}\end{array}$ & 2 & $\begin{array}{l}19.0 \pm 7.5 \times 1.5 \pm 0.5 \mu \mathrm{m} \text {, mostly simple } \\
\text { orthotropic }\end{array}$ & $\begin{array}{l}\text { cylindrical to narrowly } \\
\text { ellipsoidal, } 4.5 \pm 1.0 \times 2.0 \pm \\
0.5 \mu \mathrm{m}\end{array}$ & $\begin{array}{l}\text { Gonçalves } \\
\text { et al. (2020) }\end{array}$ \\
\hline E. humicola & - & - & $\begin{array}{l}20-45 \times 1.5-2.5 \mu \mathrm{m} \text {, producing a } \\
\text { succession of phialospores }\end{array}$ & $\begin{array}{l}\text { ellipsoidal, 5-8 }(-10) \times 2.0- \\
3.5 \mu \mathrm{m}\end{array}$ & $\begin{array}{l}\text { Cain (1956); } \\
\text { Grosklags and } \\
\text { Swift (1957) }\end{array}$ \\
\hline E. koreana & $\begin{array}{l}\text { On PDA reaching } 15.5 \mathrm{~mm} \\
\text { in } 7 \mathrm{~d} \text {; on OA reaching } 17 \\
\mathrm{~mm} \text { in } 7 \mathrm{~d} \text {; on MEA } \\
\text { reaching } 27.5 \mathrm{~mm} \text { in } 7 \mathrm{~d}\end{array}$ & $2.2-3.9$ & $(15.5-) 31.5-40(-59) \times 2(-2.5) \mu \mathrm{m}$ & $\begin{array}{l}\text { ellipsoidal or oblong- } \\
\text { ellipsoidal, 3-4(-5) } \times 1.5- \\
2(-2.5) \mu \mathrm{m}\end{array}$ & $\begin{array}{l}\text { Phookamsak } \\
\text { et al. (2019) }\end{array}$ \\
\hline E. maritima & $\begin{array}{l}\text { On } O A \text { and MEA reaching } \\
35-40 \mathrm{~mm} \text { after } 9-10 \mathrm{~d} \text {. }\end{array}$ & $3.5-4.5$ & $(17-) 20-26(-29) \times 1-2 \mu \mathrm{m}$ & $\begin{array}{l}\text { ellipsoidal-piriform, } 6.5- \\
\text { 8.0(- } 9.0) \times(2.0-) 2.5-3.3(- \\
\text { 4.0) } \mu \mathrm{m}\end{array}$ & $\begin{array}{l}\text { Belyakova } \\
(1970)\end{array}$ \\
\hline E. microspora & $\begin{array}{l}\text { On Czapek Dox agar, } \\
\text { reaching } 40 \mathrm{~mm} \text { after } 14 \mathrm{~d}\end{array}$ & 2.9 & $\begin{array}{l}25-60 \times 2-3 \mu \mathrm{m} \text { (up to } 95 \mu \mathrm{m} \text { long), } \\
\text { mostly unbranched, usually septate near } \\
\text { the base }\end{array}$ & $\begin{array}{l}\text { ovoid to ellipsoidal, } 3.0- \\
10.0 \times 1.5-4.0 \mu \mathrm{m}\end{array}$ & $\begin{array}{l}\text { Backus and } \\
\text { Orpurt (1961) }\end{array}$ \\
\hline E. minima & $\begin{array}{l}\text { On OA reaching } 30 \mathrm{~mm} \text { in } 7 \\
\mathrm{~d}\end{array}$ & 4.3 & $20-30 \times 2-2.5 \mu \mathrm{m}$ & ellipsoidal, 4-10×2-3.5 $\mu \mathrm{m}$ & Stolk (1955) \\
\hline E. mirabilis & - & - & $30-50 \times 3 \mu \mathrm{m}$ & $\begin{array}{l}\text { oblong-ellipsoidal, or of } \\
\text { cylindrical one-guttulate, } 6- \\
11 \times 2.5-3 \mu \mathrm{m} \text {, usually } 8 \times \\
3 \mu \mathrm{m}\end{array}$ & $\begin{array}{l}\text { Malan (1952); } \\
\text { Stolk } 1955\end{array}$ \\
\hline E. pallida & $\begin{array}{l}\text { On OA reaching } 35 \mathrm{~mm} \text { in } 9 \\
\mathrm{~d}\end{array}$ & 3.9 & $25-45 \times 1.5-2 \mu \mathrm{m}$ & $\begin{array}{l}\text { ovoid to ovoid-cylindrical, } \\
\text { (3.2-) } 4-5.2(-7.8) \times 1.5-2.5 \\
(-3.3) \mu \mathrm{m}\end{array}$ & $\begin{array}{l}\text { Belyakova } \\
(1974)\end{array}$ \\
\hline E. persica & $\begin{array}{l}\text { On MEA growing slower, } \\
\text { reaching } 17-18 \mathrm{~mm} \text { diam in } \\
7 \mathrm{~d}\end{array}$ & $1.9-2.0$ & $30-40 \times 2-2.5 \mu \mathrm{m}$ & $\begin{array}{l}\text { narrowly ellipsoidal, } 4.5- \\
6.5 \times 2 \mu \mathrm{m} \text {, adhering in } \\
\text { slimy heads }\end{array}$ & $\begin{array}{l}\text { Hyde et al. } \\
\text { (2016) }\end{array}$ \\
\hline E. phycophila & $\begin{array}{l}\text { On OA reaching } 36 \mathrm{~mm} \text { in } \\
\text { diam in } 21 \mathrm{~d}\end{array}$ & 1.7 & $\begin{array}{l}21.0 \pm 5.0 \times 2.0 \pm 0.5 \mu \mathrm{m} \text {, lateral branches } \\
\text { form }\end{array}$ & $\begin{array}{l}\text { circular to oblong- } \\
\text { ellipsoidal, mean } \pm \mathrm{SD}= \\
5.5 \pm 2.5 \times 3.5 \pm 1.5 \mu \mathrm{m}\end{array}$ & $\begin{array}{l}\text { Gonçalves } \\
\text { et al. (2020) }\end{array}$ \\
\hline E. pusilla & - & - & $\begin{array}{l}33-79 \times 1.5-2.5 \mu \mathrm{m} \text {, conidiophores } \\
\text { developing as lateral branches on subaerial } \\
\text { hyphae, long, erect, slender, spirally } \\
\text { produced }\end{array}$ & $\begin{array}{l}\text { oblong, ovoid to } \\
\text { obpyriform, } 4.5-10.5 \times 2.25- \\
4.5 \mu \mathrm{m}\end{array}$ & $\begin{array}{l}\text { Mathur and } \\
\text { Thirumalachar } \\
\text { (1962) }\end{array}$ \\
\hline E. robusta & $\begin{array}{l}\text { Colonies } 18-20 \mathrm{~mm} \text { diam in } \\
10 \mathrm{~d}\end{array}$ & $1.8-2.0$ & $\begin{array}{l}20-65 \times 2.5-5.0 \mu \mathrm{m} \text {, phialides simple or } \\
\text { with whorled branching, with a short } \\
\text { apical wall thickening }\end{array}$ & $\begin{array}{l}\text { cylindrical, slightly truncated } \\
\text { at the base, } 13-17.5 \times 3.8- \\
4.5 \mu \mathrm{m}, \mathrm{L} / \mathrm{W} \text { 3.5-3.9 }\end{array}$ & Gams (1971) \\
\hline $\begin{array}{l}\text { E. } \\
\text { salmosynnemata }\end{array}$ & - & - & $\begin{array}{l}14.0-38 \times 0.75-1.5 \mu \mathrm{m} \text {, conidiophores } \\
\text { arising along entire length of synnemata, } \\
\text { septate only at base, unbranched }\end{array}$ & $\begin{array}{l}\text { ellipsoidal or ovoid, } 3.4- \\
6.4 \times 2.3-3.4 \mu \mathrm{m}\end{array}$ & $\begin{array}{l}\text { Grosklags and } \\
\text { Swift (1957) }\end{array}$ \\
\hline E. sphaerospora & $\begin{array}{l}\text { On OA agar reaching } 55-60 \\
\mathrm{~mm} \text { in } 2 \mathrm{wk}\end{array}$ & $3.9-4.3$ & $\begin{array}{l}\text { 16-32 } \times 2-3 \text { um, simple, discrete, awl- } \\
\text { shaped, with no distinct coliarette }\end{array}$ & $\begin{array}{l}\text { ellipsoidal to cylindrical or } \\
\text { allantoid, } 3-8 \times 1.5-3 \text { um, }\end{array}$ & $\begin{array}{l}\text { Udagawa and } \\
\text { Furuya (1988) }\end{array}$ \\
\hline
\end{tabular}


Table 2 Morphological comparison of Emericellopsis spp. (Continued)

\begin{tabular}{|c|c|c|c|c|c|}
\hline Species & Colonies & $\begin{array}{l}\text { Growth } \\
\text { rate } \\
(\mathrm{mm} / \mathrm{d})\end{array}$ & Conidiogenous cells/Conidiophores & Conidial shape and size & References \\
\hline & & & & aggregating in slimy heads & \\
\hline E. stolkiae & $\begin{array}{l}\text { On CMA agar reaching } 40- \\
44 \mathrm{~mm} \text { in } 14 \mathrm{~d}\end{array}$ & $2.9-3.1$ & $\begin{array}{l}18-40 \times 3-3 \mu \mathrm{m} \text {, mostly unbranched, rarely } \\
\text { forked }\end{array}$ & $\begin{array}{l}\text { ovoid, } 3.5-8.4 \times 2.2-5 \mu \mathrm{m} \text {, } \\
\text { most often } 4.3-5.7 \times 3.3- \\
3.8 \mu \mathrm{m}\end{array}$ & $\begin{array}{l}\text { Davidson and } \\
\text { Christensen } \\
\text { (1971) }\end{array}$ \\
\hline E. synnematicola & - & - & $\begin{array}{l}\text { conidiophores arising from synnemata, } 2- \\
3 \mathrm{~mm} \text { long }\end{array}$ & $\begin{array}{l}\text { ovoid-ellipsoidal, } 3.5-6.5 \times \\
2-3 \mu \mathrm{m}\end{array}$ & $\begin{array}{l}\text { Mathur and } \\
\text { Thirumalachar } \\
\text { (1960) }\end{array}$ \\
\hline $\begin{array}{l}\text { E. synnematicola } \\
\text { var. mangus }\end{array}$ & Reaching $40 \mathrm{~mm}$ in $15 \mathrm{~d}$ & 2.7 & $\begin{array}{l}\text { synnemata erect, distributed uniformly in } \\
\text { the colony, up to } 4 \mathrm{~mm} \text { high, cream- } \\
\text { coloured, bearing prominent slimy conidial } \\
\text { heads; conidiophores simple or branched }\end{array}$ & $\begin{array}{l}\text { globose to subglobose, } 2.5- \\
7.5 \mu \mathrm{m}\end{array}$ & $\begin{array}{l}\text { Leelavathy } \\
\text { (1966) }\end{array}$ \\
\hline E. terricola & $\begin{array}{l}\text { On } O A \text { reaching } 5-6 \mathrm{~cm} \\
\text { after } 2 \text { mo }\end{array}$ & $0.8-1.0$ & $30-40 \times 2-3 \mu \mathrm{m}$ & $\begin{array}{l}\text { ellipsoidal or ovoid, one or } \\
\text { two oil droplets, } 6-8 \times 3.3- \\
4 \mu \mathrm{m}\end{array}$ & $\begin{array}{l}\text { Van Beyma } \\
\text { Thoe Kingma } \\
\text { (1939) }\end{array}$ \\
\hline
\end{tabular}

11550 (Terfehr et al. 2014). However, these Acremonium species, A. chrysogenum, S. strictum, A flavum and Cephalosporium polyvaleurum, are not part of the Emericellopsis clade.

The $\mathrm{G}+\mathrm{C}$ content of $E$. atlantica was $54.2 \%$, which is higher than the median (48.9\%) for Pezizomycotina (Storck 1966; Nishida 2015) and the average for Ascomycota (>50\%) (Li and Du 2014). High GC content has been indicated to play a role in complex environmental adaptation and horizontal gene transfer (Mann and Chen 2010) and is linked with halotolerance in prokaryotes (Jacob 2012). High GC content has also been linked with thermal stability of the DNA through base pair stacking (Yakovchuk et al. 2006), higher affinity of the histones (Nishida 2015), and lower occurrence of transposable elements (TEs) (Muszewska et al. 2017), while high AT content has been linked to anaerobic fungi (Wilken et al. 2020). This indicates that E. atlantica is adapted to an environment with high salt content or an environment with active exchange of genes, increasing the GC content, which in turn decreased the portion of TEs. The amount of SSRs were only about $1.16 \%$ in $E$. atlantica, $4.32 \%$ in $A$. encephaloides and $1.48 \%$ in $C$. marina. The fragmentation of the genomes makes it difficult to assess the amount of SSRs accurately.

Of the different gene clusters with characterized compounds that were detected in E. atlantica, only botrydial has not been described from Acremonium or Emericellopsis. The total number of BGCs detected by antiSMASH were 35 clusters, slightly lower than average for Sordariomycetes (Rokas et al. 2018; Robey et al. 2020). Isolates within Emericellopsis are capable of producing a range of NRPS-derived peptides (Cole and Rolinson 1961; Argoudelis et al. 1974; Ishiyama et al. 2000; Rogozhin et al. 2018; Baranova et al. 2019). This indicates that E. atlantica is a promising source of potentially novel
NRPS produced peptides. However, application of the OSMAC (One Strain Many Compounds) approach in culturing or heterologous expression and gene-knockout experiments may be needed to produce these putatively novel NRPS-peptides and characterize the gene clusters (De Mattos-Shipley et al. 2018).

Comparison of terrestrial and marine fungal genomes are still in an early phase. A study of Hypoxylaceae revealed that two closely related species of different origin (terrestrial vs marine) showed a relatively low portion, $5.5 \%$, of species-specific genes in the marine isolate (Wibberg et al. 2021). The authors hypothesized that these genes might be involved in osmotolerance and nutrient uptake. Few of these specific genes had characterized functions, and it is therefore difficult to assess the marine nature of isolates based on genomic information alone. In addition, epigenetic modification may play a large role in adaptations to different environments (Kronholm et al. 2016). Further comparison and characterizations of genes and genomes and their regulation are needed to understand the specific adaptations of marine fungi.

\section{Biosystematics and sexual reproduction of Emericellopsis atlantica}

Morphologically, E. atlantica is differentiated from the other Emericellopsis species in the marine and alkaline clade by irregularly shaped guttules and longer phialides. The distinct morphology supported the phylogenetic placement on a separate branch within the marine clade of Emericellopsis, closely related to E. pallida and E. phycophila that are morphologically different. The major branches in the three clades of "terrestrial", marine and "soda soil" Emericellopsis were supported in both Bayesian and maximum likelihood models. As Gonçalves et al. (2020) noted, the clades do not contain species with the 
same traits and isolation locality. Emericellopsis cladophorae and E. enteromorphae were isolated from algae in estuarine environments and were placed in the "alkaline soda soil" and "terrestrial" clade, respectively. The long branches of the terrestrial clade were likely induced by missing data in three to four of the six loci in terrestrial isolates (Wiens 2006; Darriba et al. 2016) and in the three newly described species in Gonçalves et al. (2020). Only one of the terrestrial sequences, E. minima CBS871.68, contained all six loci. The close relation of these species makes it difficult to establish proper phylogenetic relations without sequence data from several loci. The lack of sequence data, together with "Acremonium" species in each of the three clades, as well as the placement of the algae associated E. cladophorae and $E$. enteromorphae outside of the marine clade supports the necessity of a taxonomic revision of the genus (Gonçalves et al. 2020).

Despite the lack of sporocarps during isolation and culturing, E. atlantica contained a complete MAT1-1 mating locus (sla2, MATa3, MATa2, MATa1, apn1 and cox6a) on scaffold_14 and pheromone sensing protein. This indicates that sexual reproduction and sporocarp formation could be possible in the species if MAT1-2 exists (Klix et al. 2010). However, one can ask the question whether sexual reproduction would take place in the sponge-host in deep-sea environment. It is possible that the fungus is present elsewhere in other marine substrates or habitats that could function as suitable places for sexual reproduction.

\section{A generalist fungus with ability to degrade marine biomass}

The growth characterization showed that the preferred substrate of E. atlantica was 0.4MEA and sponge extract in seawater. The slowest growth occurred in media prepared with distilled water. Emericellopsis atlantica grew on the control media, which means it could also utilize agar alone as a nutrient source. The results shows that the fungus prefers saline conditions with complex nutrient sources, at least in axenic laboratory culture. A growth optimum temperature of above $20^{\circ} \mathrm{C}$ is similar to what is observed in some other marine fungi (Philomena 1980; Lorenz and Molitoris 1992; Pang et al. 2011). Emericellopsis atlantica grows at $2^{\circ} \mathrm{C}$, which makes it a psychrotrophic fungus (Hassan et al. 2016; Wang et al. 2017). The adaptation of E. atlantica to the marine environment is further supported by the presence of CAZyme classes relating to utilization of marine polysaccharides such as fucose, carrageenan and laminarin. However, no modular sulfatases with a CAZyme domain as described in Helbert (2017) were predicted from the JGI annotation. A manual search using the SulfAtlas database (Barbeyron et al. 2016) revealed several
CAZymes with low E score against putative sulfatases and sulfatase domains. However, they did not contain the conserved peptide pattern of the catalytic site. Many marine polysaccharides have attached sulfate groups and removal of those is necessary for utilization of the sugars (Schultz-Johansen et al. 2018; Kappelmann et al. 2019). Emericellopsis atlantica contained six putative sulfatases, without CAZyme domains, annotated by JGI in the genome, which is three times more than $A$. encephaloides and C. marina, but less than the terrestrial species (11 and 22 genes). Emericellopsis atlantica lacked genes for polyphenol oxidase, of which the activity has been observed in degradation assays in the terrestrial clade of Emericellopsis (Zuccaro et al. 2004; Grum-Grzhimaylo et al. 2013). Marine clade Emericellopsis spp. were unable to degrade polyphenols. The absence of polyphenol oxidase and the presence of fucosidase (GH29/95/141) is in line with the detected phenotype of the marine clade of Emericellopsis (Zuccaro et al. 2004). The absence of polyphenol oxidase indicates that $E$. atlantica does not degrade gallotannins and ellagitannins from terrestrial sources (Cammann et al. 1989; Salminen et al. 2002; Zuccaro et al. 2004). There are other types of tannins such as phlorotannins in brown algae and other enzymes may be required to degrade them (Jormalainen et al. 2003; Zuccaro et al. 2004). Loss of the ability to break down gallotannins and ellagitannins is likely a specialization to the available substrates in the marine environment (Zuccaro et al. 2004).

Generalists tend to have a higher amount of CAZymes than specialists do in order to utilize a wider range of substrates (Zhao et al. 2014). Emericellopsis atlantica showed a wider range of enzymatic classes than the other fungi in this study (176 different classes). Considering that $E$. atlantica did not have the highest number of genes, but still had the highest diversity of enzymatic classes indicates an adaptation to utilize a wide diversity of substrates. The ability to process any source of nutrients efficiently would be beneficial in a nutrient poor ocean environment (Turley 2000). Sponges are natural filters for organic matter such as marine snow and naturally concentrate the availability of different nutrients, therefore fungi may exploit this by living within the sponge and adapt specifically to that environment (Anteneh et al. 2019).

Polysaccharide lyases occurred in fewer numbers in terrestrial saprophytic and facultative parasitic fungi, where some even lacked PLs altogether (Soanes et al. 2008; Zhao et al. 2014). PLs have been shown to be related to breakdown of pectins from cell walls in marine diatoms and seagrasses (Desikachary and Dweltz 1961; Ovodova et al. 1968; Hehemann et al. 2017; Hobbs et al. 2019). Emericellopsis atlantica had almost twice the number of PLs (17) compared to the other fungi in the 
CAZyme analysis. Interestingly, the number of PLs was significantly higher than in $A$. niger which is used as an industrial producer of different CAZymes (Chettri et al. 2020). Furthermore, the relative number of CAZymes with secretory signal was also high (38\%). This indicates that $E$. atlantica can break down cell remnants in marine snow or pectin rich substrates in marine sediments or within the sponge host (Smith et al. 1992).

The presence of DNA photolyases in the genome could indicate that the species is not specifically adapted to dark deep-sea environments (Núñez-Pons et al. 2018). Partial loss of photolyases has previously been reported in white-nose fungi from bats as an adaptation to darkness (Palmer et al. 2018). The host sponge Stelletta normani was collected from $1350 \mathrm{~m}$ depth, but the type specimen of the species was collected from $330 \mathrm{~m}$ depth in Southern Norway (Sollas 1880). Other sources report specimens collected from the twilight (dysphotic) zone with small amounts of light penetration (Murillo et al. 2012). The sponge occurrence is not restricted to the deep-sea environment, which makes it logical that the associated $E$. atlantica has not lost its photolyases and is not an obligate deep-sea dweller.

\section{CONCLUSION}

Emericellopsis atlantica is the first genome sequenced Emericellopsis species and a distinct marine fungus showing adaptations to utilize a range of different substrates in the marine environment. The nature of the relationship to the host sponge cannot be determined based on this single isolate. A large portion of predicted genes have unknown or general function prediction only, which underlines the need to sequence more genomes for comparative genomic analyses to identify possible mechanisms of adaptations. The E. atlantica genome also contained several unknown NRPS clusters and enzymes that warrant future research and may be of biotechnological and industrial interest. The three genomes we have presented here will contribute to the increased number of available marine fungal genomes and shedding light on the characteristics of marine fungi.

\footnotetext{
ABBREVIATIONS

1KFG: The 1000 fungal genomes; AA: Auxiliary activity; ASW: Artificial seawater; BGC: Biosynthetic gene cluster; CAZymes: Carbohydrate active enzymes; CBM: Carbohydrate binding module; CE: Carboxyl esterases; CEGMA: Core Eukaryotic Genes Mapping Approach; DEPC: Diethyl pyrocarbonate; DNA: Deoxyribonucleic acid; EC: Enzyme classification; GH: Glycoside hydrolase; GT: Glycosyl transferase; ITS: NrDNA internal transcribed spacer region; JGI: Joint Genome Institute; KEGG: Kyoto Encyclopedia of Genes and Genomes; KOG: Eukaryotic Orthologous Groups of proteins; MEA: Malt extract agar; NRPS: Non-ribosomal peptide synthase; OA: Oatmeal agar; OSMAC: One strain many compounds; PCR: Polymerase chain reaction; PDA: Potato dextrose agar; PKS: Polyketide synthase; PL: Polysaccharide lyase; RiPP: Ribosomally synthesized and posttranslationally modified peptide; RNA: Ribonucleic acid; rpb2: Gene for the second largest subunit of RNA polymerase II; SSR: Short simple repeats;
}

TE: Transposable elements; tef1: Transcription elongation factor 1 gene; tub2: Tubulin beta chain gene

\section{Supplementary Information}

The online version contains supplementary material available at https://doi. org/10.1186/s43008-021-00072-0.

Additional file 1 : Supplementary data 1. Sequencing details and statistics regarding library and method for assembly for each species.

Additional file 2 : Supplementary data 2. Overview of fungal accessions used with type status, isolation source and model selection for phylogenetic analysis.

Additional file $\mathbf{3}$ : Supplementary data 3. Phylogenetic tree produced by PhyML webpage used as supporting data for Fig. 1.

Additional file 4 : Supplementary data 4. Overview of functional and enzymatic classes of genes using KEGG and KOG annotation.

Additional file $\mathbf{5}$ : Supplementary data $\mathbf{5}$. Overview of detected classes, numbers of each class, number of genes with secretion signal.

Additional file 6 : Supplementary data $\mathbf{6}$. Graphic output from synteny analysis of BGCs in E. atlantica.

Additional file 7 : Supplementary data 7. Bioactivity data of fractions produced from fermentation of E. atlantica.

\section{Acknowledgements}

Bernard Picton (Ulster Museum) and Christine Morrow (Queens University Belfast) performed the identification of the host sponge. Ronald de Vries and Ad Wiebenga (Westerdijk Institute) provided extraction protocols. Marte Jenssen (Marbio) cultured Emericellopsis atlantica for DNA and RNA extraction. The Norwegian marine biobank (Marbank) provided the sponge extract used in the culturing study. Marte Albrigtsen and Kirsti Helland (Marbio) ran the bioassays.

\section{Adherence to national and international regulations}

Genetic resources used in this study adhere to national and international regulations (Nagoya Protocol of the Convention on Biological Diversity), as the UK materials used were accessed in accordance with applicable legislation of the providing country (sampled before 12 October 2015).

\section{Authors' contributions}

$\mathrm{OCH}, \mathrm{TR}, \mathrm{JHA}, \mathrm{EHH}$ and BA conceived the idea, aims and designed the experiments. TDSS isolated E. atlantica, TR isolated C. marina and A. encephaloides. SAJ and ADWD did initial screening of E. atlantica. CL optimized DNA and RNA extraction protocols. OCH cultured and extracted metabolites, analyzed genomic and MS data, performed phylogenetic analysis and visualized the findings. $\mathrm{KL}$ and MA prepared the libraries and sequenced the fungi, JP and WA assembled the genomes, AL assembled the transcriptomes and $\mathrm{RH}$ annotated them. The sequencing effort at JGI was coordinated by VN. JWS has been the PI for the sequencing of the three genomes. JHA, EHH, TR, BA and EK supervised and mentored $\mathrm{OCH}$. $\mathrm{LH}$ compared, visualized and wrote the description of the morphology of $E$. atlantica. JHA, IVG, RJC, PWC and ADWD have provided funding and materials for the completion of this project. OCH and TR wrote the first draft of the manuscript. OCH, TR, EK, JHA, EHH, BA, CL, RJC, PWC, IVG, JWS and ADWD have reviewed and commented the manuscript. All authors have read through and accepted the manuscript for publication.

\footnotetext{
Funding

Digibiotics (Digital Life Norway) and Centre for New Antibacterial Strategies at UiT The Arctic University of Norway, through the Research Council of Norway (Project 269425) provided funding for Teppo Rämä. This research was performed within the Community Sequence Program "1KFG" conducted by the U.S. Department of Energy Joint Genome Institute, a DOE Office of Science User Facility, which was supported by the Office of Science of the U.S. Department of Energy under contract DE-AC02-05CH11231. This work benefitted from the sharing of expertise within the DFG priority program "Taxon-Omics: New Approaches for Discovering and Naming Biodiversity" (SPP 1991) to RJC and EK.
} 


\section{Availability of data and materials}

The trees generated and/or analyzed during the current study are available in the TreeBASE repository, http://purl.org/phylo/treebase/phylows/study/ TB2:S27616. Genomes and annotations are submitted to NCBI/GenBank under the accessions: PRJNA571189 (E. atlantica), PRJNA347005 (A. encephaloides), PRJNA347008 (C. marina).

They are also available at MycoCosm from the following links:

E. atlantica: https://mycocosm.jgi.doe.gov/Emericellopsis_atlantica

A. encephaloides: https://mycocosm.jgi.doe.gov/Amylocarpus_encephaloides

C. marina: https://mycocosm.jgi.doe.gov/Calycina_marina

All data generated or analyzed during this study are included in this

published article, accessions and its supplementary data files. Raw data used in the study are available from the corresponding author on request.

\section{DECLARATIONS}

Ethics approval and consent to participate

Not applicable.

\section{Consent for publication}

Not applicable.

\section{Competing interests}

The authors declare that they have no competing interests.

\section{Author details}

${ }^{1}$ Marbio, The Norwegian College of Fishery Science, Department at Faculty of Biosciences, Fisheries and Economics, UiT The Arctic University of Norway, Tromsø, Norway. ${ }^{2}$ Westerdijk Fungal Biodiversity Institute, Uppsalalaan 8, 3584CT Utrecht, Netherlands. ${ }^{3}$ The Norwegian Structural Biology Centre (NorStruct), Department of Chemistry, Faculty of Science and Technology, UiT the Arctic University of Norway, Tromsø, Norway. ${ }^{4}$ Institute of Organic Chemistry and BMWZ, Leibniz Universität Hannover, Hanover, Germany. ${ }^{5}$ Department of Botany and Plant Pathology, Oregon State University, Corvallis, USA. ${ }^{6}$ US Department of Energy Joint Genome Institute, Lawrence Berkeley National Laboratory, Berkeley, CA 94720, USA. ${ }^{7}$ Department of Plant and Microbial Biology, University of California Berkeley, Berkeley, CA 94720, USA. ${ }^{8}$ School of Microbiology, University College Cork, Cork, Ireland. ${ }^{9} \mathrm{MaREI}$ Centre, Environmental Research Institute, University College Cork, Cork, Ireland. ${ }^{10} \mathrm{APC}$ Microbiome Ireland, Cork, Ireland.

\section{Received: 24 January 2021 Accepted: 25 July 2021}

\section{Published online: 09 August 2021}

\section{REFERENCES}

Andersen MR, Salazar MP, Schaap PJ, Van De Vondervoort PJ, Culley D, Thykaer J, Frisvad JC, Nielsen KF, Albang R, Albermann K, Berka RM, Braus GH, BrausStromeyer SA, Corrochano LM, Dai Z, Van Dijck PW, Hofmann G, Lasure LL, Magnuson JK, Menke H, Meijer M, Meijer SL, Nielsen JB, Nielsen ML, Van Ooyen AJ, Pel HJ, Poulsen L, Samson RA, Stam H, Tsang A, Van Den Brink JM, Atkins A, Aerts A, Shapiro H, Pangilinan J, Salamov A, Lou Y, Lindquist E, Lucas S, Grimwood J, Grigoriev IV, Kubicek CP, Martinez D, Van Peij NN, Roubos JA, Nielsen J, Baker SE (2011) Comparative genomics of citric-acidproducing Aspergillus niger ATCC 1015 versus enzyme-producing CBS 513.88. Genome Research 21(6):885-897. https://doi.org/10.1101/gr.112169.110

Anisimova M, Gascuel O (2006) Approximate likelihood-ratio test for branches: a fast, accurate, and powerful alternative. Systematic Biology 55(4):539-552. https://doi.org/10.1080/10635150600755453

Anisimova M, Gil M, Dufayard J-F, Dessimoz C, Gascuel O (2011) Survey of branch support methods demonstrates accuracy, power, and robustness of fast likelihood-based approximation schemes. Systematic Biology 60(5):685-699. https://doi.org/10.1093/sysbio/syr041

Anteneh YS, Brown MH, Franco CMM (2019) Characterization of a halotolerant fungus from a marine sponge. BioMed Research International 2019:3456164. https://doi.org/10.1155/2019/3456164

Araki Y, Awakawa T, Matsuzaki M, Cho R, Matsuda Y, Hoshino S, Shinohara Y, Yamamoto M, Kido Y, Inaoka DK, Nagamune K, Ito K, Abe I, Kita K (2019) Complete biosynthetic pathways of ascofuranone and ascochlorin in Acremonium egyptiacum. Proceedings of the National Academy of Sciences 116(17):8269-8274. https://doi.org/10.1073/pnas.1819254116
Argoudelis AD, Dietz A, Johnson LE (1974) Zervamicins I and II, polypeptide antibiotics produced by Emericellopsis salmosynnemata. The Journal of Antibiotics 27(5):321-328. https://doi.org/10.7164/antibiotics.27.321

Backus MP, Orpurt PA (1961) A new Emericellopsis from Wisconsin, with notes on other species. Mycologia 53(1):64-83. https://doi.org/10.1080/00275514.1 961.12017934

Bankevich A, Nurk S, Antipov D, Gurevich AA, Dvorkin M, Kulikov AS, Lesin VM, Nikolenko SI, Pham S, Prjibelski AD, Pyshkin AV, Sirotkin AV, Vyahhi N, Tesler G, Alekseyev MA, Pevzner PA (2012) SPAdes: a new genome assembly algorithm and its applications to single-cell sequencing. Journal of Computational Biology 19(5):455-477. https://doi.org/10.1089/cmb.2012.0021

Baral HO, Rämä T (2015) Morphological update on Calycina marina (Pezizellaceae, Helotiales, Leotiomycetes), a new combination for Laetinaevia marina. Botanica Marina 58(6):523-534. https://doi.org/10.1515/bot-2015-0049

Baranova AA, Rogozhin EA, Georgieva ML, Bilanenko EN, Kul'ko AB, Yakushev AV, Alferova VA, Sadykova VS (2019) Antimicrobial peptides produced by alkaliphilic fungi Emericellopsis alkalina: biosynthesis and biological activity against pathogenic multidrug-resistant fungi. Applied Biochemistry and Microbiology 55(2):145-151. https://doi.org/10.1134/S0003683819020030

Barbeyron T, Brillet-Guéguen L, Carré W, Carrière C, Caron C, Czjzek M, Hoebeke M, Michel G (2016) Matching the diversity of sulfated biomolecules: creation of a classification database for sulfatases reflecting their substrate specificity. PLoS One 11(10):e0164846. https://doi.org/10.1371/journal.pone.0164846

Barbosa Al, Coutinho AJ, Costa Lima SA, Reis S (2019) Marine polysaccharides in pharmaceutical applications: fucoidan and chitosan as key players in the drug delivery match field. Marine Drugs 17(12):654. https://doi.org/10.3390/ md17120654

Batista-García RA, Sutton T, Jackson SA, Tovar-Herrera OE, Balcázar-López E, Sánchez-Carbente MDR, Sánchez-Reyes A, Dobson ADW, Folch-Mallol JL (2017) Characterization of lignocellulolytic activities from fungi isolated from the deep-sea sponge Stelletta normani. PLoS One 12(3):e0173750. https://doi. org/10.1371/journal.pone.0173750

Belyakova L (1970) New species of the genus Emericellopsis (Euroticaeae). Mikologiya i Fitopatologiya 4:530-531

Belyakova L (1974) Genus Emericellopsis van Beyma (Eurotiaceae). Mikologiya i Fitopatologiya 8:385-395

Berteau O, Mccort I, Goasdoué N, Tissot B, Daniel R (2002) Characterization of a new alpha-L-fucosidase isolated from the marine mollusk Pecten maximus that catalyzes the hydrolysis of alpha-L-fucose from algal fucoidan (Ascophyllum nodosum). Glycobiology 12(4):273-282. https://doi.org/10.1093/ glycob/12.4.273

Blin K, Shaw S, Steinke K, Villebro R, Ziemert N, Lee SY, Medema MH, Weber T (2019) antiSMASH 5.0: updates to the secondary metabolite genome mining pipeline. Nucleic Acids Research 47(W1):W81-W87. https://doi.org/10.1093/na r/gkz310

Boraston AB, Bolam DN, Gilbert HJ, Davies GJ (2004) Carbohydrate-binding modules: fine-tuning polysaccharide recognition. The Biochemical Journal 382(3):769-781. https://doi.org/10.1042/BJ20040892

Buchfink B, Xie C, Huson DH (2015) Fast and sensitive protein alignment using DIAMOND. Nature Methods 12(1):59-60. https://doi.org/10.1038/nmeth.3176

Bushnell B (2014) BBTools software package. http://sourceforge.net/projects/ bbmap

Busk PK, Pilgaard B, Lezyk MJ, Meyer AS, Lange L (2017) Homology to peptide pattern for annotation of carbohydrate-active enzymes and prediction of function. BMC Bioinformatics 18(1):214. https://doi.org/10.1186/s12859-017-1 625-9

Cain RF (1956) Studies of soil fungi: Saturnomycetes, a new genus of the Aspergillaceae. Canadian Journal of Botany 34(1):135-141. https://doi.org/1 0.1139/b56-013

Cammann J, Denzel K, Schilling G, Gross GG (1989) Biosynthesis of gallotannins: $\beta$-glucogallin-dependent formation of 1,2,3,4,6-pentagalloylglucose by enzymatic galloylation of 1,2,3,6-tetragalloylglucose. Archives of Biochemistry and Biophysics 273(1):58-63. https://doi.org/10.1016/0003-9861(89)90161-6

Carroll AR, Copp BR, Davis RA, Keyzers RA, Prinsep MR (2020) Marine natural products. Natural Product Reports 37(2):175-223. https://doi.org/10.1039/ C9np00069k

Chettri D, Verma AK, Verma AK (2020) Innovations in CAZyme gene diversity and its modification for biorefinery applications. Biotechnology Reports 28: e00525. https://doi.org/10.1016/j.btre.2020.e00525

Cole M, Rolinson GN (1961) 6-Aminopenicillanic acid. II. Formation of 6aminopenicillanic acid by Emericellopsis minima (Stolk) and related fungi. 
Proceedings of the Royal Society B: Biological Sciences 154:490-497. https:// doi.org/10.1098/rspb.1961.0046

Collén PN, Jeudy A, Sassi J-F, Groisillier A, Czjzek M, Coutinho PM, Helbert W (2014) A novel unsaturated $\beta$-glucuronyl hydrolase involved in ulvan degradation unveils the versatility of stereochemistry requirements in family GH105. The Journal of Biological Chemistry 289(9):6199-6211. https://doi. org/10.1074/jbc.M113.537480

Crous PW, Verkley GJM, Groenewald JZ, Houbraken J (2019) Fungal biodiversity. In: CBS laboratory manual series vol. 1, 2nd edn. Westerdijk Fungal Biodiversity Institute, Utrecht

Darriba D, Weiß M, Stamatakis A (2016) Prediction of missing sequences and branch lengths in phylogenomic data. Bioinformatics 32(9):1331-1337. https://doi.org/10.1093/bioinformatics/btv768

Davidson DE, Christensen M (1971) Emericellopsis stolkiae sp. nov. from saline soils in Wyoming. Transactions of the British Mycological Society 57(3):385-391. https://doi.org/10.1016/S0007-1536(71)80053-0

de Castro E, Sigrist CJ, Gattiker A, Bulliard V, Langendijk-Genevaux PS, Gasteiger E, Bairoch A, Hulo N (2006) ScanProsite: detection of PROSITE signature matches and ProRule-associated functional and structural residues in proteins. Nucleic Acids Research 34(suppl_2):W362-W365. https://doi.org/10.1 093/nar/gkl124

de Mattos-Shipley KMJ, Greco C, Heard DM, Hough G, Mulholland NP, Vincent JL, Micklefield J, Simpson TJ, Willis CL, Cox RJ, Bailey AM (2018) The cycloaspeptides: uncovering a new model for methylated nonribosomal peptide biosynthesis. Chemical Science 9(17):4109-4117. https://doi.org/10.1 039/C8SC00717A

Desikachary TV, Dweltz N (1961) The chemical composition of the diatom frustule. Proceedings of the Indian Academy of Sciences-Section B 53(4):157165 https://link.springer.com/content/pdf/10.1007/BF03051518.pdf

Dobrinčić A, Balbino S, Zorić Z, Pedisić S, Bursać Kovačević D, Elez Garofulić I, Dragović-Uzelac V (2020) Advanced technologies for the extraction of marine brown algal polysaccharides. Marine Drugs 18(3):168. https://doi.org/10.3390/ md18030168

Duc PM, Hatai K, Kurata O, Tensha K, Yoshitaka U, Yaguchi T, Udagawa S-I (2009) Fungal infection of mantis shrimp (Oratosquilla oratoria) caused by two anamorphic fungi found in Japan. Mycopathologia 167(5):229-247. https:// doi.org/10.1007/s1 1046-008-9174-4

Eddy SR (2020) HMMER: biosequence analysis using profile hidden Markov models. HMMER development team http://hmmer.org/

Fouillaud M, Venkatachalam M, Llorente M, Magalon H, Cuet P, Dufossé L (2017) Biodiversity of pigmented fungi isolated from marine environment in La Réunion Island, Indian Ocean: new resources for colored metabolites. Journal of Fungi 3(3):36. https://doi.org/10.3390/jof3030036

Gams W (1971) Cephalosporium-artige Schimmelpilze (Hyphomycetes). Gustav Fischer Verlag, Stuttgart

Gams W (1975) Cephalosporium-like hyphomycetes: some tropical species. Transactions of the British Mycological Society 64(3):389-404. https://doi. org/10.1016/50007-1536(75)80138-0

GBIF Secretariat (2021) GBIF backbone taxonomy. GBIF Secretariat, GBIF.org. https://doi.org/10.15468/39omei Accessed 02 Mar 2021

Gilchrist CLM, Chooi Y-H (2021) clinker and clustermap.js: automatic generation of gene cluster comparison figures. Bioinformatics:1-3. https://doi.org/10.1 093/bioinformatics/btab007

Goffeau A, Barrell BG, Bussey H, Davis RW, Dujon B, Feldmann H, Galibert F, Hoheisel JD, Jacq C, Johnston M, Louis EJ, Mewes HW, Murakami Y, Philippsen P, Tettelin H, Oliver SG (1996) Life with 6000 genes. Science 274(5287):546-567. https://doi.org/10.1126/science.274.5287.546

Gonçalves MFM, Vicente TFL, Esteves AC, Alves A (2020) Novel halotolerant species of Emericellopsis and Parasarocladium associated with macroalgae in an estuarine environment. Mycologia 112(1):154-171. https://doi.org/10.1080/ 00275514.2019 .1677448

Grabherr MG, Haas BJ, Yassour M, Levin JZ, Thompson DA, Amit I, Adiconis X, Fan L, Raychowdhury R, Zeng Q, Chen Z, Mauceli E, Hacohen N, Gnirke A, Rhind N, Di Palma F, Birren BW, Nusbaum C, Lindblad-Toh K, Friedman N, Regev A (2011) Full-length transcriptome assembly from RNA-Seq data without a reference genome. Nature Biotechnology 29(7):644-652. https://doi.org/10.1 038/nbt.1883

Grigoriev IV, Cullen D, Goodwin SB, Hibbett D, Jeffries TW, Kubicek CP, Kuske C, Magnuson JK, Martin F, Spatafora JW, Tsang A, Baker SE (2011) Fueling the future with fungal genomics. Mycology 2(3):192-209 https://www.ta ndfonline.com/doi/full/10.1080/21501203.2011.584577
Grigoriev IV, Nikitin R, Haridas S, Kuo A, Ohm R, Otillar R, Riley R, Salamov A, Zhao X, Korzeniewski F, Smirnova T, Nordberg H, Dubchak I, Shabalov I (2014) Mycocosm portal: gearing up for 1000 fungal genomes. Nucleic Acids Research 42(D1):D699-D704. https://doi.org/10.1093/nar/gkt1 183

Grosklags JH, Swift ME (1957) The perfect stage of an antibiotic_producing Cephalosporium. Mycologia 49(3):305-317. https://doi.org/10.1080/00275514.1 957.12024646

Grum-Grzhimaylo AA, Georgieva ML, Debets AJM, Bilanenko EN (2013) Are alkalitolerant fungi of the Emericellopsis lineage (Bionectriaceae) of marine origin? IMA Fungus 4(2):213-228. https://doi.org/10.5598/imafungus.2013.04. 02.07

Guindon S, Dufayard J-F, Lefort V, Anisimova M, Hordijk W, Gascuel O (2010) New algorithms and methods to estimate maximum-likelihood phylogenies: assessing the performance of PhyML 3.0. Systematic Biology 59(3):307-321. https://doi.org/10.1093/sysbio/syq010

Haefner B (2003) Drugs from the deep: marine natural products as drug candidates. Drug Discovery Today 8(12):536-544. https://doi.org/10.1016/S13 59-6446(03)02713-2

Hassan N, Rafiq M, Hayat M, Shah AA, Hasan F (2016) Psychrophilic and psychrotrophic fungi: a comprehensive review. Reviews in Environmental Science and Bio/Technology 15(2):147-172. https://doi.org/10.1007/s11157-01 6-9395-9

Hehemann J-H, Truong LV, Unfried F, Welsch N, Kabisch J, Heiden SE, Junker S, Becher D, Thürmer A, Daniel R, Amann R, Schweder T (2017) Aquatic adaptation of a laterally acquired pectin degradation pathway in marine Gammaproteobacteria. Environmental Microbiology 19(6):2320-2333. https:// doi.org/10.1111/1462-2920.13726

Helbert W (2017) Marine polysaccharide sulfatases. Frontiers in Marine Science 4(6). https://doi.org/10.3389/fmars.2017.00006

Hobbs JK, Hettle AG, Vickers C, Boraston AB (2019) Biochemical reconstruction of a metabolic pathway from a marine bacterium reveals its mechanism of pectin depolymerization. Applied and Environmental Microbiology 85(1): e02114-e02118. https://doi.org/10.1128/AEM.02114-18

Hsiao G, Wang S-W, Chiang Y-R, Chi W-C, Kuo Y-H, Phong D, Chen C-Y, Lee T-H (2020) Anti-inflammatory effects of peptides from a marine algicolous fungus Acremonium sp. NTU492 in BV-2 microglial cells. Journal of Food and Drug Analysis 28(2):283-291. https://doi.org/10.38212/2224-6614.1062

Huang Q, Rodgers JM, Hemley RJ, Ichiye T (2017) Extreme biophysics: enzymes under pressure. Journal of Computational Chemistry 38(15):1174-1182. https://doi.org/10.1002/jcc.24737

Hunter S, Apweiler R, Attwood TK, Bairoch A, Bateman A, Binns D, Bork P, Das U, Daugherty L, Duquenne L, Finn RD, Gough J, Haft D, Hulo N, Kahn D, Kelly E, Laugraud A, Letunic I, Lonsdale D, Lopez R, Madera M, Maslen J, Mcanulla C, Mcdowall J, Mistry J, Mitchell A, Mulder N, Natale D, Orengo C, Quinn AF, Selengut JD, Sigrist CJ, Thimma M, Thomas PD, Valentin F, Wilson D, Wu CH, Yeats C (2009) InterPro: the integrative protein signature database. Nucleic Acids Research 37(suppl_1):D211-D215. https://doi.org/10.1093/nar/gkn785

Hyde KD, Hongsanan S, Jeewon R, Bhat DJ, Mckenzie EHC, Jones EBG, Phookamsak R, Ariyawansa HA, Boonmee S, Zhao Q, Abdel-Aziz FA, Abdel-Wahab MA, Banmai S, Chomnunti P, Cui B-K, Daranagama DA, Das K, Dayarathne MC, De Silva NI, Dissanayake AJ, Doilom M, Ekanayaka AH, Gibertoni TB, Góes-Neto A, Huang S-K, Jayasiri SC, Jayawardena RS, Konta S, Lee HB, Li W-J, Lin C-G, Liu J-K, Lu Y-Z, Luo Z-L, Manawasinghe IS, Manimohan P, Mapook A, Niskanen T, Norphanphoun C, Papizadeh M, Perera RH, Phukhamsakda C, Richter C, De A, ALCM S, Drechsler-Santos ER, Senanayake IC, Tanaka K, TMDS T, Thambugala KM, Tian Q, Tibpromma S, Thongbai B, Vizzini A, Wanasinghe DN, Wijayawardene NN, Wu H-X, Yang J, Zeng X-Y, Zhang H, Zhang J-F, Bulgakov TS, Camporesi E, Bahkali AH, Amoozegar MA, Araujo-Neta LS, Ammirati JF, Baghela A, Bhatt RP, Bojantchev D, Buyck B, Da Silva GA, De Lima CLF, De Oliveira RJV, De Souza CF, Dai Y-C, Dima B, Duong TT, Ercole E, Mafalda-Freire F, Ghosh A, Hashimoto A, Kamolhan S, Kang J-C, Karunarathna SC, Kirk PM, Kytövuori I, Lantieri A, Liimatainen K, Liu Z-Y, Liu X-Z, Lücking R, Medardi G, Mortimer PE, Nguyen TTT, Promputtha I, KNA R, Reck MA, Lumyong S, Shahzadeh-Fazeli SA, Stadler M, Soudi MR, Su H-Y, Takahashi T, Tangthirasunun N, Uniyal P, Wang Y, Wen T-C, Xu J-C, Zhang Z-K, Zhao Y-C, Zhou J-L, Zhu L (2016) Fungal diversity notes 367-490: taxonomic and phylogenetic contributions to fungal taxa. Fungal Diversity 80(1):1-270. https://doi.org/10.1 007/s13225-016-0373-x

Ishiyama D, Satou T, Senda H, Fujimaki T, Honda R, Kanazawa S (2000) Heptaibin, a novel antifungal peptaibol antibiotic from Emericellopsis sp. BAUA8289. The Journal of Antibiotics 53(7):728-732. https://doi.org/10.7164/antibiotics.53.728 
Jackson SA, Sutton T, Bromley CL, Young RM, O'gara F, Baker BJ, Dobson ADW (2016) Potent antibacterial fungi isolated from a deep-sea sponge. In: 11th international marine biotechnology conference held by international marine biotechnology association and Institute of Marine and Environmental Technology in Baltimore, Maryland, USA, p 68 http://theimba.org/s/IMBC201 6-Abstract-Book.pdf

Jacob J (2012) Classification of halophilic heterotrophic bacteria thriving in the Jordanian Dead Sea littoral zone. Journal of Biological Sciences 12:246-252. https://doi.org/10.3923/jbs.2012.246.252

Johnston PR, Quijada L, Smith CA, Baral H-O, Hosoya T, Baschien C, Pärtel K, Zhuang W-Y, Haelewaters D, Park D, Carl S, López-Giráldez F, Wang Z, Townsend JP (2019) A multigene phylogeny toward a new phylogenetic classification of Leotiomycetes. IMA Fungus 10(1):1. https://doi.org/10.1186/s43 008-019-0002-x

Jormalainen V, Honkanen T, Koivikko R, Eränen J (2003) Induction of phlorotannin production in a brown alga: defense or resource dynamics? Oikos 103(3): 640-650. https://doi.org/10.1034/j.1600-0706.2003.12635.x

Kalyaanamoorthy S, Minh BQ, Wong TKF, Von Haeseler A, Jermiin LS (2017) ModelFinder: fast model selection for accurate phylogenetic estimates. Nature Methods 14(6):587-589. https://doi.org/10.1038/nmeth.4285

Kanehisa M, Goto S, Sato Y, Furumichi M, Tanabe M (2012) KEGG for integration and interpretation of large-scale molecular data sets. Nucleic Acids Research 40(D1):D109-D114. https://doi.org/10.1093/nar/gkr988

Kappelmann L, Krüger K, Hehemann J-H, Harder J, Markert S, Unfried F, Becher D, Shapiro N, Schweder T, Amann RI, Teeling H (2019) Polysaccharide utilization loci of North Sea Flavobacteriia as basis for using SusC/D-protein expression for predicting major phytoplankton glycans. The ISME Journal 13(1):76-91. https://doi.org/10.1038/s41396-018-0242-6

Katoh K, Misawa K, Kuma Kl, Miyata T (2002) MAFFT: a novel method for rapid multiple sequence alignment based on fast Fourier transform. Nucleic Acids Research 30(14):3059-3066. https://doi.org/10.1093/nar/gkf436

Katoh K, Standley DM (2013) MAFFT multiple sequence alignment software version 7: improvements in performance and usability. Molecular Biology and Evolution 30(4):772-780. https://doi.org/10.1093/molbev/mst010

Kennedy J, Flemer B, Jackson SA, Morrissey JP, O'gara F, Dobson ADW (2014) Evidence of a putative deep sea specific microbiome in marine sponges. PLoS One 9(3):e91092. https://doi.org/10.1371/journal.pone.0091092

Kis-Papo T, Weig AR, Riley R, Peršoh D, Salamov A, Sun H, Lipzen A, Wasser SP, Rambold G, Grigoriev IV, Nevo E (2014) Genomic adaptations of the halophilic Dead Sea filamentous fungus Eurotium rubrum. Nature Communications 5(1):3745. https://doi.org/10.1038/ncomms4745

Klix V, Nowrousian M, Ringelberg C, Loros JJ, Dunlap JC, Pöggeler S (2010) Functional characterization of MAT1-1-specific mating-type genes in the homothallic ascomycete Sordaria macrospora provides new insights into essential and nonessential sexual regulators. Eukaryotic Cell 9(6):894-905. https://doi.org/10.1128/EC.00019-10

Köljalg U, Nilsson RH, Abarenkov K, Tedersoo L, Taylor AFS, Bahram M, Bates ST, Bruns TD, Bengtsson-Palme J, Callaghan TM, Douglas B, Drenkhan T, Eberhardt U, Dueñas M, Grebenc T, Griffith GW, Hartmann M, Kirk PM, Kohout $P$, Larsson E, Lindahl BD, Lücking R, Martín MP, Matheny PB, Nguyen NH, Niskanen T, Oja J, Peay KG, Peintner U, Peterson M, Põldmaa K, Saag L, Saar I, Schüßler A, Scott JA, Senés C, Smith ME, Suija A, Taylor DL, Telleria MT, Weiss M, Larsson K-H (2013) Towards a unified paradigm for sequence-based identification of fungi. Molecular Ecology 22(21):5271-5277. https://doi.org/1 $0.1111 /$ mec. 12481

Koonin EV, Fedorova ND, Jackson JD, Jacobs AR, Krylov DM, Makarova KS, Mazumder R, Mekhedov SL, Nikolskaya AN, Rao BS, Rogozin IB, Smirnov S, Sorokin AV, Sverdlov AV, Vasudevan S, Wolf Yl, Yin JJ, Natale DA (2004) A comprehensive evolutionary classification of proteins encoded in complete eukaryotic genomes. Genome Biology 5(2):R7. https:/doi.org/10.1186/gb-2004-5-2-r7

Krogh A, Larsson B, Von Heijne G, Sonnhammer EL (2001) Predicting transmembrane protein topology with a hidden Markov model: application to complete genomes. Journal of Molecular Biology 305(3):567-580. https:// doi.org/10.1006/jmbi.2000.4315

Kronholm I, Johannesson H, Ketola T (2016) Epigenetic control of phenotypic plasticity in the filamentous fungus Neurospora crassa. G3: Genes|Genomes|Genetics 6(12):4009. https://doi.org/10.1534/g3.116.033860

Lanfear R, Calcott B, Ho SY, Guindon S (2012) PartitionFinder: combined selection of partitioning schemes and substitution models for phylogenetic analyses. Molecular Biology and Evolution 29(6):1695-1701. https://doi.org/10.1093/ molbev/mss020
Lanfear R, Frandsen PB, Wright AM, Senfeld T, Calcott B (2017) PartitionFinder 2: new methods for selecting partitioned models of evolution for molecular and morphological phylogenetic analyses. Molecular Biology and Evolution 34(3):772-773. https://doi.org/10.1093/molbev/msw260

Lee S, Park MS, Lee H, Kim J-J, Eimes JA, Lim YW (2019) Fungal diversity and enzyme activity associated with the macroalgae, Agarum clathratum. Mycobiology 47(1):50-58. https://doi.org/10.1080/12298093.2019.1580464

Leelavathy KM (1966) Emericellopsis synnematicola var. magnus var. nov. Current Science 35(18):470-471 http://www.jstor.org/stable/24063724

Lefort V, Longueville J-E, Gascuel O (2017) SMS: smart model selection in PhyML. Molecular Biology and Evolution 34(9):2422-2424. https://doi.org/10.1093/ molbev/msx149

Lei XG, Weaver JD, Mullaney E, Ullah AH, Azain MJ (2013) Phytase, a new life for an "old" enzyme. Annual Review of Animal Biosciences 1(1):283-309. https:// doi.org/10.1146/annurev-animal-031412-103717

Li X-Q, Du D (2014) Variation, evolution, and correlation analysis of C+G content and genome or chromosome size in different kingdoms and phyla. PLoS One 9(2):e88339. https://doi.org/10.1371/journal.pone.0088339

Loque CP, Medeiros AO, Pellizzari FM, Oliveira EC, Rosa CA, Rosa LH (2010) Fungal community associated with marine macroalgae from Antarctica. Polar Biology 33(5):641-648. https://doi.org/10.1007/s00300-009-0740-0

Lorenz R, Molitoris HP (1992) Combined influence of salinity and temperature (Phoma-pattern) on growth of marine fungi. Canadian Journal of Botany 70(10):2111-2115. https://doi.org/10.1139/b92-262

Lücking R, Aime MC, Robbertse B, Miller AN, Ariyawansa HA, Aoki T, Cardinali G, Crous PW, Druzhinina IS, Geiser DM, Hawksworth DL, Hyde KD, Irinyi L, Jeewon R, Johnston PR, Kirk PM, Malosso E, May TW, Meyer W, Öpik M, Robert V, Stadler M, Thines M, Vu D, Yurkov AM, Zhang N, Schoch CL (2020) Unambiguous identification of fungi: where do we stand and how accurate and precise is fungal DNA barcoding? IMA Fungus 11(1):14. https://doi.org/1 0.1186/s43008-020-00033-z

Malan CE (1952) Sopra un interessante plectomicete umicolo nuovo per la scienza: Peyronellula mirabilis n.g. et n.sp. Mycopathologia et Mycologia Applicata 6(3):164-175. https://doi.org/10.1007/BF02081433

Mann S, Chen YP (2010) Bacterial genomic G+C composition-eliciting environmental adaptation. Genomics 95(1):7-15. https://doi.org/10.1016/j. ygeno.2009.09.002

Mathur PN, Thirumalachar MJ (1960) A new Emericellopsis species with Stilbellatype of conidia. Mycologia 52(5):694-697 https://doi.org/10.2307/3755869

Mathur PN, Thirumalachar MJ (1962) Studies on some Indian soil fungi. II. On some new or interesting ascomycetes. Sydowia 16(1-6):45-56 https://www. zobodat.at/pdf/Sydowia_16_0046-0056.pdf

Michel G, Nyval-Collen P, Barbeyron T, Czjzek M, Helbert W (2006) Bioconversion of red seaweed galactans: a focus on bacterial agarases and carrageenases. Applied Microbiology and Biotechnology 71(1):23-33. https://doi.org/10.1 007/s00253-006-0377-7

Minh BQ, Nguyen MAT, Von Haeseler A (2013) Ultrafast approximation for phylogenetic bootstrap. Molecular Biology and Evolution 30(5):1188-1195. https://doi.org/10.1093/molbev/mst024

Mitsuguchi H, Seshime Y, Fujii I, Shibuya M, Ebizuka Y, Kushiro T (2009) Biosynthesis of steroidal antibiotic fusidanes: functional analysis of oxidosqualene cyclase and subsequent tailoring enzymes from Aspergillus fumigatus. Journal of the American Chemical Society 131(18):6402-6411. https://doi.org/10.1021/ja8095976

Mouton M, Postma F, Wilsenach J, Botha A (2012) Diversity and characterization of culturable fungi from marine sediment collected from St. Helena bay, South Africa. Microbial Ecology 64(2):311-319. https:/doi.org/10.1007/s00248-012-0035-9

Murillo FJ, Muñoz PD, Cristobo J, Ríos P, González C, Kenchington E, Serrano A (2012) Deep-sea sponge grounds of the Flemish cap, Flemish pass and the grand banks of Newfoundland (Northwest Atlantic Ocean): distribution and species composition. Marine Biology Research 8(9):842-854. https://doi.org/1 $0.1080 / 17451000.2012 .682583$

Muszewska A, Steczkiewicz K, Stepniewska-Dziubinska M, Ginalski K (2017) Cutand-paste transposons in fungi with diverse lifestyles. Genome Biology and Evolution 9(12):3463-3477. https://doi.org/10.1093/gbe/evx261

Naranjo-Ortiz MA, Gabaldón T (2019) Fungal evolution: major ecological adaptations and evolutionary transitions. Biological Reviews 94(4):1443-1476. https://doi.org/10.1111/brv.12510

NCBI (2021) Genome list - genome - NCBI. National Library of medicine (US), National Center for Biotechnology Information, Bethesda https://www.ncbi. nlm.nih.gov/genome/browse/\#!/eukaryotes/ Accessed 07 Jan 2021 
NCBI Resource Coordinators (2018) Database resources of the national center for biotechnology information. Nucleic Acids Research 46(D1):D8-D13. https:// doi.org/10.1093/nar/gkx1095

Nguyen L-T, Schmidt HA, Von Haeseler A, Minh BQ (2014) IQ-TREE: a fast and effective stochastic algorithm for estimating maximum-likelihood phylogenies. Molecular Biology and Evolution 32(1):268-274. https://doi.org/1 0.1093/molbev/msu300

Nishida H (2015) Relationship between chromosomal GC content and isoelectric points of histones in fungi. The Journal of General and Applied Microbiology 61(1):24-26. https://doi.org/10.2323/jgam.61.24

Núñez-Pons L, Avila C, Romano G, Verde C, Giordano D (2018) UV-protective compounds in marine organisms from the Southern Ocean. Marine Drugs 16(9):336. https://doi.org/10.3390/md16090336

Oey I (2016) Effects of high pressure on enzymes. In: Balasubramaniam VM, Barbosa-Cánovas GV, Lelieveld HLM (eds) High pressure processing of food: principles, technology and applications. Springer, New York, pp 391-431. https://doi.org/10.1007/978-1-4939-3234-4_19

Ovodova RG, Vaskovsky VE, Ovodov YS (1968) The pectic substances of Zosteraceae. Carbohydrate Research 6(3):328-332. https://doi.org/10.1016/ S0008-6215(00)81454-8

Palmer JM, Drees KP, Foster JT, Lindner DL (2018) Extreme sensitivity to ultraviolet light in the fungal pathogen causing white-nose syndrome of bats. Nature Communications 9(1):35. https://doi.org/10.1038/s41467-017$02441-z$

Pang K-L, Chow RK, Chan C-W, Vrijmoed LP (2011) Diversity and physiology of marine lignicolous fungi in Arctic waters: a preliminary account. Polar Research 30(1):5859. https://doi.org/10.3402/polar.v30i0.5859

Parra G, Bradnam K, Korf I (2007) CEGMA: a pipeline to accurately annotate core genes in eukaryotic genomes. Bioinformatics 23(9):1061-1067. https://doi. org/10.1093/bioinformatics/btm071

Parra G, Bradnam K, Ning Z, Keane T, Korf I (2009) Assessing the gene space in draft genomes. Nucleic Acids Research 37(1):289-297. https://doi.org/10.1 093/nar/gkn916

Paz Z, Komon-Zelazowska M, Druzhinina IS, Aveskamp MM, Shnaiderman A, Aluma Y, Carmeli S, llan M, Yarden O (2010) Diversity and potential antifungal properties of fungi associated with a Mediterranean sponge. Fungal Diversity 42(1):17-26. https://doi.org/10.1007/s13225-010-0020-x

Petersen TN, Brunak S, Von Heijne G, Nielsen H (2011) SignalP 4.0: discriminating signal peptides from transmembrane regions. Nature Methods 8(10):785-786. https://doi.org/10.1038/nmeth.1701

Philomena MTC (1980) The effect of temperature, $\mathrm{pH}$, light and dark on the growth of fungi from Irish coastal waters. Mycologia 72(2):350-358. https:// doi.org/10.2307/3759258

Phookamsak R, Hyde KD, Jeewon R, Bhat DJ, Jones EBG, Maharachchikumbura SSN, Raspé O, Karunarathna SC, Wanasinghe DN, Hongsanan S, Doilom M, Tennakoon DS, Machado AR, Firmino AL, Ghosh A, Karunarathna A, Mešić A, Dutta AK, Thongbai B, Devadatha B, Norphanphoun C, Senwanna C, Wei D, Pem D, Ackah FK, Wang G-N, Jiang H-B, Madrid H, Lee HB, Goonasekara ID, Manawasinghe IS, Kušan I, Cano J, Gené J, Li J, Das K, Acharya K, Raj KNA, Latha KPD, Chethana KWT, He M-Q, Dueñas M, Jadan M, Martín MP, Samarakoon MC, Dayarathne MC, Raza M, Park MS, Telleria MT, Chaiwan N, Matočec N, De Silva NI, Pereira OL, Singh PN, Manimohan P, Uniyal P, Shang Q-J, Bhatt RP, Perera RH, Alvarenga RLM, Nogal-Prata S, Singh SK, Vadthanarat S, Oh S-Y, Huang S-K, Rana S, Konta S, Paloi S, Jayasiri SC, Jeon SJ, Mehmood T, Gibertoni TB, Nguyen TTT, Singh U, Thiyagaraja V, Sarma W, Dong W, Yu X-D, Lu Y-Z, Lim YW, Chen Y, Tkalčec Z, Zhang Z-F, Luo Z-L, Daranagama DA, Thambugala KM, Tibpromma S, Camporesi E, Bulgakov TS, Dissanayake AJ, Senanayake IC, Dai DQ, Tang L-Z, Khan S, Zhang H, Promputtha I, Cai L, Chomnunti P, Zhao R-L, Lumyong S, Boonmee S, Wen T-C, Mortimer PE, Xu J (2019) Fungal diversity notes 929-1035: taxonomic and phylogenetic contributions on genera and species of fungi. Fungal Diversity 95(1):1-273. https://doi.org/10.1007/s13225-019-00421-w

Pinedo C, Wang CM, Pradier JM, Dalmais B, Choquer M, Le Pêcheur P, Morgant G, Collado IG, Cane DE, Viaud M (2008) Sesquiterpene synthase from the botrydial biosynthetic gene cluster of the phytopathogen Botrytis cinerea. ACS Chemical Biology 3(12):791-801. https://doi.org/10.1021/cb800225V

Ponce NMA, Pujol CA, Damonte EB, Flores MXAL, Stortz CA (2003) Fucoidans from the brown seaweed Adenocystis utricularis: extraction methods, antiviral activity and structural studies. Carbohydrate Research 338(2):153-165. https:// doi.org/10.1016/S0008-6215(02)00403-2

Prasannarai K, Sridhar K (2004) A note on first record of marine fungus Amylocarpus encephaloides in tropics. Ecology, Environment and
Conservation 10(2):103-106 https://www.researchgate.net/publication/26744 7940_A_note_on_first_record_of_marine_fungus_Amylocarpus_encepha loides_in_tropics

Rämä T, Mathiassen G, Kauserud H (2014) Marine fungi new to Norway, with an outlook to the overall diversity. Agarica 35:35-47 https://www.researchgate. net/publication/282777747_Marine_fungi_new_to_Norway_with_an_ outlook_to_the_overall_diversity

Rédou V, Navarri M, Meslet-Cladière L, Barbier G, Burgaud G (2015) Species richness and adaptation of marine fungi from deep-subseafloor sediments. Applied and Environmental Microbiology 81(10):3571-3583. https://doi.org/1 0.1128/aem.04064-14

Reisky L, Préchoux A, Zühlke M-K, Bäumgen M, Robb CS, Gerlach N, Roret T, Stanetty C, Larocque R, Michel G, Song T, Markert S, Unfried F, Mihovilovic MD, Trautwein-Schult A, Becher D, Schweder T, Bornscheuer UT, Hehemann J-H (2019) A marine bacterial enzymatic cascade degrades the algal polysaccharide ulvan. Nature Chemical Biology 15(8):803-812. https://doi. org/10.1038/s41589-019-0311-9

Robey MT, Caesar LK, Drott MT, Keller NP, Kelleher NL (2020) An interpreted atlas of biosynthetic gene clusters from 1000 fungal genomes. bioRxiv:2020.2009. 2021.307157. https://doi.org/10.1101/2020.09.21.307157

Rogozhin EA, Sadykova VS, Baranova AA, Vasilchenko AS, Lushpa VA, Mineev KS, Georgieva ML, Kul'ko AB, Krasheninnikov ME, Lyundup AV, Vasilchenko AV, Andreev YA (2018) A novel lipopeptaibol emericellipsin A with antimicrobial and antitumor activity produced by the extremophilic fungus Emericellopsis alkalina. Molecules 23(11):2785. https://doi.org/10.3390/molecules23112785

Rokas A, Wisecaver JH, Lind AL (2018) The birth, evolution and death of metabolic gene clusters in fungi. Nature Reviews. Microbiology 16(12):731744. https://doi.org/10.1038/s41579-018-0075-3

Ronquist F, Teslenko M, Van Der Mark P, Ayres DL, Darling A, Hohna S, Larget B, Liu L, Suchard MA, Huelsenbeck JP (2012) MrBayes 3.2: efficient Bayesian phylogenetic inference and model choice across a large model space. Systematic Biology 61(3):539-542. https://doi.org/10.1093/sysbio/sys029

Salminen J-P, Ossipov V, Pihlaja K (2002) Distribution of hydrolysable tannins in the foliage of Finnish birch species. Zeitschrift für Naturforschung $57 c(3-4)$ : 248-256. https://doi.org/10.1515/znc-2002-3-409

Sánchez-Machado DI, López-Cervantes J, López-Hernández J, Paseiro-Losada P, Simal-Lozano J (2004) Determination of the uronic acid composition of seaweed dietary fibre by HPLC. Biomedical Chromatography 18(2):90-97. https://doi.org/10.1002/bmc.297

Schor R, Schotte C, Wibberg D, Kalinowski J, Cox RJ (2018) Three previously unrecognised classes of biosynthetic enzymes revealed during the production of xenovulene A. Nature Communications 9(1):1963-1963. https://doi.org/10.1038/s41467-018-04364-9

Schultz-Johansen M, Bech PK, Hennessy RC, Glaring MA, Barbeyron T, Czjzek M, Stougaard P (2018) A novel enzyme portfolio for red algal polysaccharide degradation in the marine bacterium Paraglaciecola hydrolytica $566^{\top}$ encoded in a sizeable polysaccharide utilization locus. Frontiers in Microbiology 9:839. https://doi.org/10.3389/fmicb.2018.00839

Sharma K (2015) Fungal genome sequencing: basic biology to biotechnology. Critical Reviews in Biotechnology 36(4):743-759. https://doi.org/10.3109/073 88551.2015 .1015959

Sigler L, Zuccaro A, Summerbell R, Mitchell J, Paré J (2004) Acremonium exuviarum sp. nov., a lizard-associated fungus with affinity to Emericellopsis. Studies in Mycology 50:409-413 https://www.researchgate.net/publica tion/242206129_Acremonium_exuviarum_sp_nov_a_lizard-associa_ted_ fungus_with_affinity_to_Emericellopsis

Sigrist CJ, Cerutti L, Hulo N, Gattiker A, Falquet L, Pagni M, Bairoch A, Bucher P (2002) PROSITE: a documented database using patterns and profiles as motif descriptors. Briefings in Bioinformatics 3(3):265-274. https://doi.org/10.1093/ bib/3.3.265

Smith DC, Simon M, Alldredge AL, Azam F (1992) Intense hydrolytic enzyme activity on marine aggregates and implications for rapid particle dissolution. Nature 359(6391):139-142. https://doi.org/10.1038/359139a0

Soanes DM, Alam I, Cornell M, Wong HM, Hedeler C, Paton NW, Rattray M, Hubbard SJ, Oliver SG, Talbot NJ (2008) Comparative genome analysis of filamentous fungi reveals gene family expansions associated with fungal pathogenesis. PLoS One 3(6):e2300. https://doi.org/10.1371/journal.pone.0002300

Sollas WJ (1880) The sponge-fauna of Norway; a report on the Rev. A.M. Norman's collection of sponges from the Norwegian coast. The Annals and Magazine of Natural History; Zoology, Botany, and Geology 5(27):130-144 https://www.biodiversitylibrary.org/part/57055 
Sotero-Caio CG, Platt RN, Suh A, Ray DA (2017) Evolution and diversity of transposable elements in vertebrate genomes. Genome Biology and Evolution 9(1):161-177. https://doi.org/10.1093/gbe/evw264

Stolk AC (1955) Emericellopsis minima sp. nov. and Westerdykella ornata gen. nov., sp. nov. Transactions of the British Mycological Society 38(4):419-424. https:// doi.org/10.1016/S0007-1536(55)80046-0

Storck R (1966) Nucleotide composition of nucleic acids of fungi. II. Deoxyribonucleic acids. Journal of Bacteriology 91(1):227-230. https://doi. org/10.1128/JB.91.1.227-230.1966

Summerbell RC, Gueidan C, Guarro J, Eskalen A, Crous PW, Gupta AK, Gené J, Cano-Lira JF, Van Iperen A, Starink M, Scott JA (2018) The protean Acremonium. A. Sclerotigenum/egyptiacum: revision, food contaminant, and human disease. Microorganisms 6(3):88. https://doi.org/10.3390/microorga nisms6030088

Summerbell RC, Gueidan C, Schroers HJ, De Hoog GS, Starink M, Rosete YA Guarro J, Scott JA (2011) Acremonium phylogenetic overview and revision of Gliomastix, Sarocladium, and Trichothecium. Studies in Mycology 68:139-162. https://doi.org/10.3114/sim.2011.68.06

Terfehr D, Dahlmann TA, Specht T, Zadra I, Kürnsteiner H, Kück U (2014) Genome sequence and annotation of Acremonium chrysogenum, producer of the $\beta$ lactam antibiotic cephalosporin C. Genome Announcements 2(5):e00948e00914. https://doi.org/10.1128/genomeA.00948-14

Thines M, Aoki T, Crous PW, Hyde KD, Lücking R, Malosso E, May TW, Miller AN, Redhead SA, Yurkov AM, Hawksworth DL (2020) Setting scientific names at all taxonomic ranks in italics facilitates their quick recognition in scientific papers. IMA Fungus 11(1):25. https://doi.org/10.1186/s43008-020-00048-6

Tørresen OK, Star B, Mier P, Andrade-Navarro MA, Bateman A, Jarnot P, Gruca A, Grynberg M, Kajava AV, Promponas VJ, Anisimova M, Jakobsen KS, Linke D (2019) Tandem repeats lead to sequence assembly errors and impose multilevel challenges for genome and protein databases. Nucleic Acids Research 47(21):10994-11006. https://doi.org/10.1093/nar/gkz841

Trincone A (2018) Update on marine carbohydrate hydrolyzing enzymes: biotechnological applications. Molecules 23(4):901. https://doi.org/10.3390/ molecules23040901

Turley C (2000) Bacteria in the cold deep-sea benthic boundary layer and sediment-water interface of the NE Atlantic. FEMS Microbiology Ecology 33(2):89-99. https://doi.org/10.1111/j.1574-6941.2000.tb00731.x

Udagawa S, Furuya K (1988) Emericellopsis sphaerospora and Kernia peruviana, two new soil-borne cleistothecial ascomycetes. Mycotaxon 33:291-301

Uniprot Consortium (2013) Update on activities at the universal protein resource (UniProt) in 2013. Nucleic Acids Research 41(D1):D43-D47. https://doi.org/1 0.1093/nar/gks1068

Van Beyma Thoe Kingma FH (1939) Beschreibung einiger neuer Pilzarten aus dem Centraalbureau voor Schimmelcultures, Baarn (Nederland). Antonie Van Leeuwenhoek 6(1):263-290. https://doi.org/10.1007/BF02146191

Van Noort V, Bradatsch B, Arumugam M, Amlacher S, Bange G, Creevey C, Falk S, Mende DR, Sinning I, Hurt E, Bork P (2013) Consistent mutational paths predict eukaryotic thermostability. BMC Evolutionary Biology 13(1):7. https:// doi.org/10.1186/1471-2148-13-7

Vickers C, Liu F, Abe K, Salama-Alber O, Jenkins M, Springate CMK, Burke JE, Withers SG, Boraston AB (2018) Endo-fucoidan hydrolases from glycoside hydrolase family 107 (GH107) display structural and mechanistic similarities to a-L-fucosidases from GH29. The Journal of Biological Chemistry 293(47): 18296-18308. https://doi.org/10.1074/jbc.RA118.005134

Walz M, Kück U (1991) Polymorphic karyotypes in related Acremonium strains. Current Genetics 19(2):73-76. https://doi.org/10.1007/BF00326285

Wang G, Liu Z, Lin R, Li E, Mao Z, Ling J, Yang Y, Yin WB, Xie B (2016) Biosynthesis of antibiotic leucinostatins in bio-control fungus Purpureocillium lilacinum and their inhibition on Phytophthora revealed by genome mining. PLoS Pathogens 12(7):e1005685. https://doi.org/10.1371/journal.ppat.1005685

Wang M, Tian J, Xiang M, Liu X (2017) Living strategy of cold-adapted fungi with the reference to several representative species. Mycology 8(3):178-188. https://doi.org/10.1080/21501203.2017.1370429

Wibberg D, Stadler M, Lambert C, Bunk B, Spröer C, Rückert C, Kalinowski J, Cox RJ, Kuhnert E (2021) High quality genome sequences of thirteen Hypoxylaceae (Ascomycota) strengthen the phylogenetic family backbone and enable the discovery of new taxa. Fungal Diversity 106(1):7-28. https:// doi.org/10.1007/s13225-020-00447-5

Wiens JJ (2006) Missing data and the design of phylogenetic analyses. Journal of Biomedical Informatics 39(1):34-42. https://doi.org/10.1016/j.jbi.2005.04.001
Wilken SE, Seppälä S, Lankiewicz TS, Saxena M, Henske JK, Salamov AA, Grigoriev IV, O'malley MA (2020) Genomic and proteomic biases inform metabolic engineering strategies for anaerobic fungi. Metabol Eng Commun 10:e00107. https://doi.org/10.1016/j.mec.2019.e00107

Yakovchuk P, Protozanova E, Frank-Kamenetskii MD (2006) Base-stacking and base-pairing contributions into thermal stability of the DNA double helix. Nucleic Acids Research 34(2):564-574. https://doi.org/10.1093/nar/gkj454

Zhang H, Yohe T, Huang L, Entwistle S, Wu P, Yang Z, Busk PK, Xu Y, Yin Y (2018) dbCAN2: a meta server for automated carbohydrate-active enzyme annotation. Nucleic Acids Research 46(W1):W95-W101. https://doi.org/10.1 093/nar/gky418

Zhang T, Fei Wang N, Qin Zhang Y, Yu Liu H, Yan Yu L (2015) Diversity and distribution of fungal communities in the marine sediments of Kongsfjorden, Svalbard (high Arctic). Scientific Reports 5:14524. https://doi.org/10.1038/ srep14524

Zhang XY, Zhang Y, Xu XY, Qi SH (2013) Diverse deep-sea fungi from the South China Sea and their antimicrobial activity. Current Microbiology 67(5):525530. https://doi.org/10.1007/s00284-013-0394-6

Zhao Z, Liu H, Wang C, Xu J-R (2014) Erratum to: comparative analysis of fungal genomes reveals different plant cell wall degrading capacity in fungi. BMC Genomics 15:6. https://doi.org/10.1186/1471-2164-15-6

Zuccaro A, Schoch CL, Spatafora JW, Kohlmeyer J, Draeger S, Mitchel JI (2008) Detection and identification of fungi intimately associated with the brown seaweed Fucus serratus. Applied and Environmental Microbiology 74(4):931941. https://doi.org/10.1128/aem.01158-07

Zuccaro A, Summerbell RC, Gams W, Schroers H-J, Mitchell Jl (2004) A new Acremonium species associated with Fucus spp., and its affinity with a phylogenetically distinct marine Emericellopsis clade. Studies in Mycology 50: 283-297 https://www.studiesinmycology.org/sim/Sim50/027-A_new_A cremonium_species_associated_with_Fucus_spp.,_and_its_affinity_with_a_ phylogenetically_distinct_marine_Emericellopsis_clade.pdf

\section{Publisher's Note}

Springer Nature remains neutral with regard to jurisdictional claims in published maps and institutional affiliations.

Ready to submit your research? Choose BMC and benefit from:

- fast, convenient online submission

- thorough peer review by experienced researchers in your field

- rapid publication on acceptance

- support for research data, including large and complex data types

- gold Open Access which fosters wider collaboration and increased citations

- maximum visibility for your research: over $100 \mathrm{M}$ website views per year

At $\mathrm{BMC}$, research is always in progress.

Learn more biomedcentral.com/submissions 